\title{
Three New Diatom Species from Spring Habitats in the Northern Apennines (Emilia-Romagna, Italy)
}

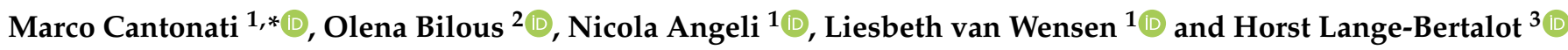 \\ 1 Limnology \& Phycology Section, MUSE-Museo delle Scienze, Corso del Lavoro e della Scienza 3, \\ I-38123 Trento, Italy; nicola.angeli@muse.it (N.A.); lhvanwensen@gmail.com (L.v.W.) \\ 2 Institute of Hydrobiology, National Academy of Sciences of Ukraine, Geroiv Stalingrada Ave., 12, \\ 04210 Kyiv, Ukraine; bilous_olena@ukr.net \\ 3 Institute for Ecology, Evolution and Diversity, Biologicum, University of Frankfurt, Max-von-Laue Straße 13, \\ 60438 Frankfurt am Main, Germany; lange-bertalot@web.de \\ * Correspondence: marco.cantonati@muse.it; Tel.: +39-0-461-270-342
}

\section{check for} updates

Citation: Cantonati, M.; Bilous, O.; Angeli, N.; van Wensen, L.; Lange-Bertalot, $\mathrm{H}$. Three New Diatom Species from Spring Habitats in the Northern Apennines (Emilia-Romagna, Italy). Diversity 2021, 13, 549. https://doi.org/ $10.3390 / \mathrm{d} 13110549$

Academic Editors: Mateja Germ, Igor Zelnik, Matthew Simpson and Michael Wink

Received: 3 October 2021

Accepted: 26 October 2021

Published: 29 October 2021

Publisher's Note: MDPI stays neutral with regard to jurisdictional claims in published maps and institutional affiliations.

Copyright: (c) 2021 by the authors Licensee MDPI, Basel, Switzerland. This article is an open access article distributed under the terms and conditions of the Creative Commons Attribution (CC BY) license (https:// creativecommons.org/licenses/by/ $4.0 /)$.

\begin{abstract}
Using light (LM, including plastid characterization on fresh material) and scanning electron microscopy (SEM), as well as a thorough morphological, physical, chemical, and biological characterization of the habitats, the present study aims at describing three species new to science. They belong to the genera Eunotia Ehrenb., Planothidium Round and L. Bukht., and Delicatophycus M.J. Wynne, and were found in two contrasting spring types in the northern Apennines. The three new species described differ morphologically from the most similar species by: less dense striae and areolae, and the absence of a ridge at the valve face-mantle transition (SEM feature) [Eunotia crassiminor Lange-Bert. et Cantonati sp. nov.; closest established species: Eunotia minor (Kütz.) Grunow]; narrower and shorter cells [Planothidium angustilanceolatum Lange-Bert. et Cantonati sp. nov.; most similar species: Planothidium lanceolatum (Bréb. ex Kütz.) Lange-Bert.]; barely-dorsiventral symmetry, set off ends, and lower density of the central dorsal striae [Delicatophycus crassiminutus Lange-Bert. et Cantonati sp. nov.; most similar species: Delicatophycus minutus M.J.Wynne]. Two of the three species we described are separated from the closest species by dimensions. Their description improved knowledge on two taxa (Eunotia minor s.l. and Planothidium lanceolatum s.l.) likely to be only partially resolved species complexes. We could also refine knowledge on the ecological profiles of the three newly-described species. Eunotia crassiminor sp. nov., as compared to Eunotia minor, appears to occur in colder inland waters with a circumneutral $\mathrm{pH}$ and a strict oligotrophy as well with respect to nitrogen. The typical habitat of Planothidium angustilanceolatum sp. nov. appears to be oligotrophic mountain flowing springs with low conductivity. Delicatophycus crassiminutus sp. nov. was observed only in limestone-precipitating springs, and is therefore likely to be restricted to hard water springs and comparable habitats where $\mathrm{CO}_{2}$ degassing leads to carbonate precipitation. Springs are a unique but severely threatened wetland type. Therefore, the in-depth knowledge of the taxonomy and ecology of characteristic diatom species is important, because diatoms are excellent indicators of the quality and integrity of these peculiar ecosystems in the face of direct and indirect human impacts.
\end{abstract}

Keywords: diatom; springs; size; Eunotia; Planothidium; Delicatophycus; taxonomy; ecology; plastids

\section{Introduction}

Springs are characterized by rich species pools at the landscape level (y diversity, [1]). They are unique habitats: multiple ecotones and extremely heterogeneous environments, offering to the sheltered organisms a wide range of environmental conditions [2]. They are also the systems where the utility of a deep integration of hydrogeological and ecological approaches becomes obvious (ecohydrogeology, [3]). However, these ecosystems are menaced by many threats, the main ones being the water-resource exploitation, and the reduction of precipitation and recharge due to climate change [4]. 
Springs have been classified in many ways, and a number of spring types have been recognized (e.g., [3]). Those relevant for the present paper are the two following, contrasting spring types: rheocrenic mountain springs with low conductivity, and limestone precipitating springs.

Rheocrenic mountain springs with low conductivity are typically high-ecologicalintegrity, oligotrophic systems with relevant discharge and current velocity. They provide a habitat to many threatened-Red-List and recently discovered species (e.g., [5]), but they are sensitive to disturbance from human activities and climate and environmental change (e.g., $[6,7])$.

Limestone precipitating springs (LPS) are a very peculiar kind of spring where hard water and $\mathrm{CO}_{2}$ degassing lead to the precipitation of carbonates. They host relatively low-diversity assemblages that however include many highly-adapted and characteristic taxa. This is the only widespread spring type clearly recognized by nature-protection legislation in the EU, but these springs are nevertheless often affected by many impacts (e.g., [8]).

Diatoms are the most diverse groups of algae in springs, where they can be excellent indicators of environmental features and ecosystem integrity [2,9]. Many rare and Red List diatom species occur in springs. Many diatom species were described from springs, and it is easy to provide examples also with reference to one of the genera discussed in the present paper, namely Eunotia: E. arcofallax Lange-Bert., E. braendlei Lange-Bert. et Werum, E. kruegeri Lange-Bert., E. palatina Lange-Bert. et W. Krüger, and E. pexii Lange-Bert. [10], E. glacialispinosa Lange-Bert. et Cantonati [11], E. cisalpina Lange-Bert. and Cantonati, E. fallacoides Lange-Bert. and Cantonati, and E. insubrica Lange-Bert. and Cantonati [12].

The importance of size in diatom species delimitation has been stressed in classical diatom literature (e.g., [13]) and current articles combining molecular and morphological approaches (e.g., [14]). Krammer [13] proposes the ratio of maximal and minimal width as a reliable means to test the quality of taxa: if $>1.5$, this ratio would point to an unresolved species complex whilst it is $<1.5$ in well-defined species. In this context, Krammer [13] also recalls Geitler's [15] first rule on life-cycle form changes: over the population developmental cycle the apical axis is shortened not only absolutely but also relatively more strongly than the transapical axis, leading to smaller specimens that are comparatively wider than larger specimens. Many diatom species were separated from the most similar species mainly on the basis of dimensions, and it is easy to provide examples as well with reference to one of the genera discussed in the present paper, namely Eunotia: E. nanopapilio Lange-Bert., and E. superpaludosa Lange-Bert. [16].

The great biogeographic and conservation importance of the Apennines is confirmed by the uniqueness of subalpine and alpine belts forming these mountains, peculiar climatic characteristics, and complex paleogeographic and paleoclimatic history of the region, combined with high geodiversity [1]. The Northern Apennines differ from the central and southern ones historically, geographically, and morphologically. They have some scattered stands of alpine vegetation, dominated by the orophilous central-European, boreal and Eurasiatic species, as well as a few limited endemics. Owing to its floristic similarity to the Alps, the summit area of the Northern Apennines has been considered as the southernmost part of a larger phytogeographic unit that also includes the main central-European massifs [17]. The described factors formed the autonomy of the Apennine communities from the Alps and central European mountains. This situation might also have favoured the discovery of new diatom species in this geographic area $[6,18]$. The focus of this paper is on the uniqueness of some representatives from three genera found in the Northern Apennines: Eunotia Ehrenb., Planothidium Round et L. Bukht., and Delicatophycus M.J.Wynne.

Eunotia Ehrenb. [19] is one of the most diverse diatom genera, consisting of more than 800 species [20] and more than 150 taxa known for Europe [16]. The morphology of the Eunotia species is characterized by dorsiventral outline, and at least one rimoportula at one apex. The species in the genus have striae which are punctate externally and interrupted 
near the ventral portion of the valve, and most representatives are characterized by a "rudimentary" raphe system [16,21]. Although some fossil Eunotia have been described from New Zealand marine sediments [20], the extant species of the genus are restricted to freshwater environments [16,22]. The genus includes many species from tropical and subtropical areas as well, inhabiting mainly oligotrophic waterbodies in the epiphyton and metaphyton [22-25]. The large majority of the Eunotia species have an ecological optimum in acidic, low conductivity, and oligo-dystrophic conditions [12,25-27]. New species of Eunotia are continuously described. Recent examples are Ruwer et al. [28]; E. nupeliana D.T.Ruwer, L.Rodrigues), and Luo et al. [21]; E. mugecuo F. Luo, Q.-M.You and Q.-X.Wang, E. filiformis F. Luo, Q.-M.You and G.-X.Wang), who worked on high elevation aquatic habitats.

The genus Planothidium F.E. Round and L. Bukhtiyarova [29] includes more than 110 names flagged as accepted taxonomically on the basis of the literature listed under the species name, according to Guiry and Guiry [30]. A search in DiatomBase [31] yielded 142 matching extant records, 67 of which have been verified by a taxonomic editor. The species of the genus have heterovalvar frustules that are usually solitary, with elliptic to lanceolate valves. Planothidium taxa are characterized by slightly concave raphe valves and have an asymmetrical central area and convex rapheless sternum valves with continuous ('delicatulum' type) or interrupted striae on one side showing a clear space in the central area [32,33]. Along with other morphological characteristics, the central area serves as a distinguishing feature for the taxa of the genus presenting a shallow depression (named sinus), a hood (also known as cavum), or the lack of both of these structures [34]. The genus is formed of species with a wide geographical distribution, from South and North America [33,35,36], Africa [37,38], Europe [39,40], Asia [34,41], to the Antarctic region (e.g., [42]). Most species are known from freshwater environments, although there are some representatives reported from brackish and marine environments, and also from aerial environments (e.g., $[43,44]$ ). The species belonging to this genus are predominantly epilithic, epipsammic, and epiphytic on aquatic plants and algae [33,34]. The species inhabit flowing and standing waters, with low to high conductivity, occur from circumneutral to alkaline waters, and seem to be tolerant up to mesotrophic conditions [33,34,45]. Examples of recently described Planothidium species are: Planothidium hinzianum C.E.Wetzel, Van de Vijver and L.Ector [34], P. potapovae C.E.Wetzel and L.Ector [34], P. sheathii Stancheva [33], P. tujii C.E.Wetzel and L.Ector [34], P. californicum Stancheva and N. Kristan [46], P. nanum Bąk, Kryk et Halabowski [47,48], and P. marganaiensis Lai, L.Ector and C.E.Wetzel [40].

Delicatophycus M.J.Wynne [49] is the correct name for the genus known as Delicata Krammer [50]. This name was invalid because it is a technical term and was amended

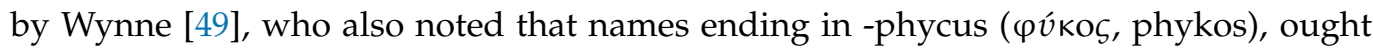
to be neutral, but were treated as masculine in accordance with tradition (International Code of Nomenclature for algae, fungi, and plants, Shenzhen Code) [51]. The current circumscription of the genus accounts for eight accepted species names [31], and 28 have been flagged as accepted taxonomically on the basis of the literature listed under the species name by Guiry and Guiry [30]. The morphology of the taxa belonging to Delicatophycus is characterized by dorsiventral valves with a lateral structure of the raphe, the presence of pseudosigmoids, the absence of apical pore fields and of stigmata, and foramina with a tendency to form undulated transapical structures externally. The species have strongly ventrally curved proximal raphe branches, distal raphe fissures deflected dorsally, with combination of the partly zig-zag shaped striae [50,52]. The representatives of the genus are found across a large climatic and geographical range: Europe [50], Asia [53,54], Africa [50], and South and North America [55,56]. The ecological preferences of the genus are still insufficiently known. However, common species of the genus are found in aerial habitats (dripping wet moss, wet rocks) and in the littoral of oligotrophic lakes [50]. Even within this relatively small genus new species are continuously described, a very recent example being Delicatophycus liuweii Y.-L. Li [57]. 
Using light microscopy (LM, both fresh and prepared materials) and scanning electron microscopy (SEM) observations, as well as a thorough morphological, physical, chemical, and biological characterization of the habitats, the present study aims to describe in detail three new species from the genera Eunotia, Planothidium and Delicatophycus found in two contrasting spring types in the Northern Apennines.

\section{Materials and Methods}

The samples on which this study is based were collected during surveys for the EBERs (Exploring the Biodiversity of Emilia-Romagna springs, 2011-2013) project [1]. Samples were collected by scraping 8-10 stones, and by collecting specimens of the dominant bryophyte species in three points of the spring area [9], and then digested using hydrogen peroxide (EN 13,946 2003 [58]). The cleaned material was mounted in Naphrax (refractive index of 1.74). Relative abundances were determined by identifying and counting a total of at least 450 valves using a Zeiss Axioskop 2 (Zeiss, Jena, Germany) and x1000 magnification.

Materials (slides, prepared material, and aliquots of the original samples), including the holotype of the new species, are held at the Diatom Collection of the MUSE-Museo delle Scienze of Trento (TR) (Northern Italy). Isotype slides and aliquots of prepared material from the same locality and substratum were deposited at the Diatom Collection of the Botanical Garden and Botanical Museum of the Freie University of Berlin (B) (Germany) and at the Diatom Collection of the Academy of Natural Sciences of Drexel University (PH) (PA, USA).

If not otherwise stated, measurements on 30 different specimens representative of the size-diminution series were made to obtain ranges and averages of the morphological and ultrastructural features.

SEM observations were carried out at the University of Frankfurt using a Hitachi S-4500 (Hitachi Ltd., Tokyo, Japan) and at the MUSE-Museo delle Scienze (Trento) using a Zeiss-EVO40XVP, Carl Zeiss SMT Ltd., Cambridge, UK at high vacuum on gold-coated stubs.

Plastid characteristics and type were assessed using Cox [59]. Terminology to describe valve morphology is based on Round et al. [22].

As concerns the typification of the new species, we chose to use the entire slide as the holotype following article 8.2 of the International Code for Botanical Nomenclature [51]. The choice for the entire population on the slide is, in our opinion, more consistent with the fact that most diatom species show an extensive variability during their population cell cycle.

In an attempt to increase data on the distribution of the three new species, both diatom and environmental data of selected springs from a comprehensive dataset of the southeastern Alps (CRENODAT Project, Biodiversity assessment and integrity evaluation of springs of Trentino-Italian Alps-and long-term ecological research, 2004-2008 [9]) were used. We looked for Planothidium angustilanceolatum sp. nov. in the epibryon samples from ten CRENODAT springs that were selected because counts included at least 100 valves of $P$. lanceolatum s.l. and because they had an ecomorphology/hydrochemistry consistent with the type locality of this species. We also looked for Delicatophycus crassiminutus sp. nov. in the epibryon slides from the five LPS included in the CRENODAT Project.

All the statistical analyses were performed within the $R$ statistical environment [60]. To find out more about the ecological preferences of Eunotia crassiminor sp. nov. as compared to Eunotia minor (Kütz.) Grunow, we considered the 12 CRENODAT sites and the 4 EBERs sites in which both species occur. If necessary, by revisiting the slide, we carefully checked the relative abundances of the two species in each site. We then calculated weighted average, mode, percentiles, minimum, and maximum for each environmental parameter, tested differences between the two species for statistical significance using $t$-tests, and illustrated the preferences of the two species for each factor for which there was a significant difference with box plots (Figure 3a-1). The R packages used for these Eunotia analyses were corrplot, weights, and ENmisc. For the biometry part of the study, all relevant morphological 
parameters listed in Table 2 were measured on 100 raphe-valves and 100 rapheless-valves of Planothidium angustilanceolatum sp. nov. and P. lanceolatum (Bréb. ex Kütz.) Lange-Bert., respectively. The R package plotrix was used for this Planothidium analysis.

\section{Results}

Eunotia crassiminor Lange-Bert. et Cantonati sp. nov. (Figures 1 and 2)

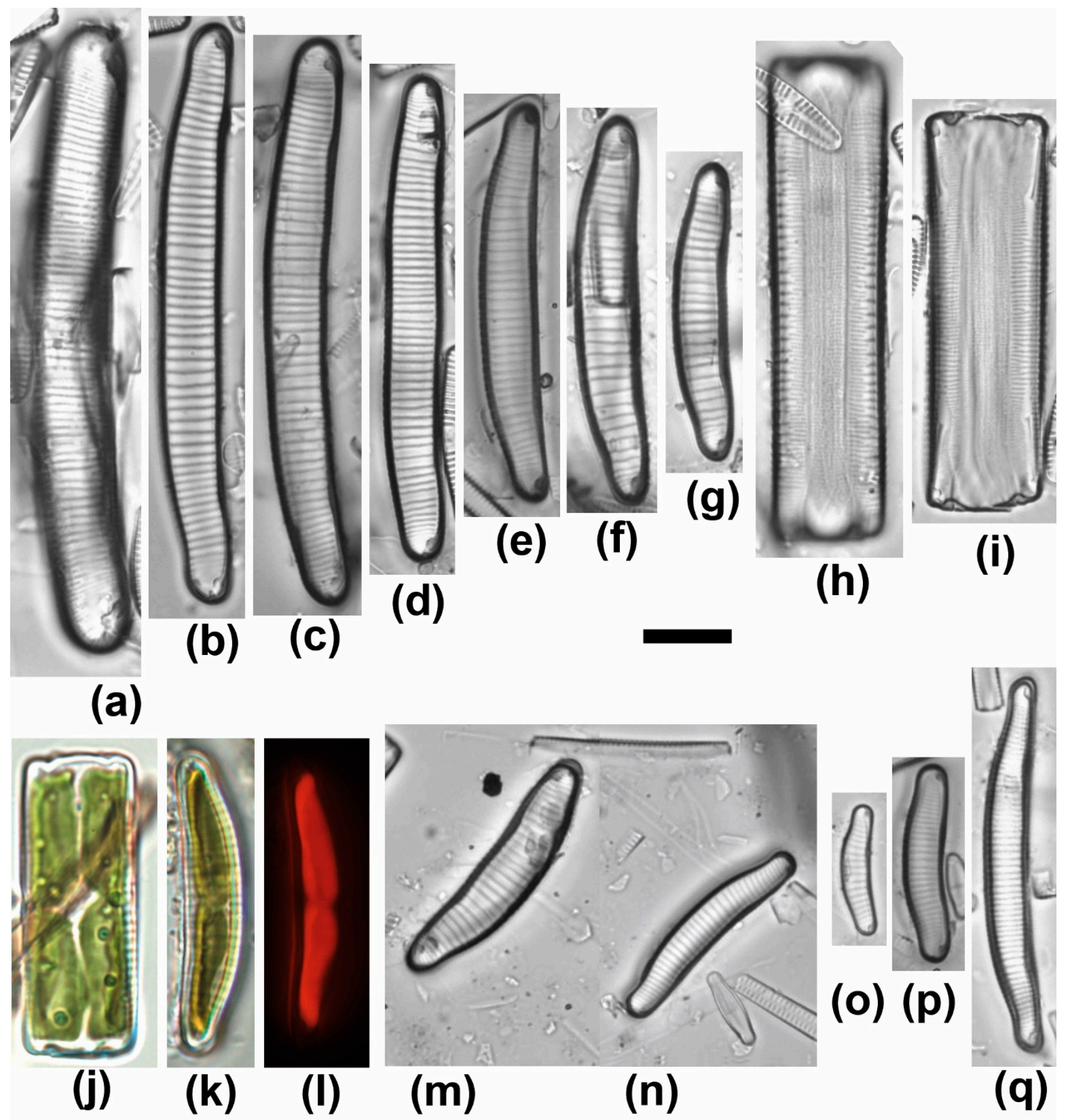

Figure 1. LM morphology of Eunotia crassiminor Lange-Bert. et Cantonati sp. nov. (a-g,k-q): valve views. (h-j): girdle views. (a): initial cell. ( $\mathbf{j}, \mathbf{k})$ : Chromoplast morphology. $(\mathbf{i}, \mathbf{m}-\mathbf{q})$ : Eunotia minor specimens shown for comparison. All micrographs bright field, with the exception of 12 which is based on chlorophyll autofluorescence. Scale bar $10 \mu \mathrm{m}$. 


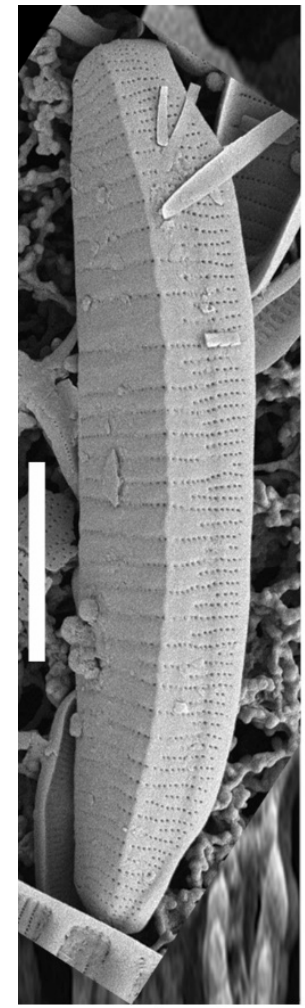

(a)

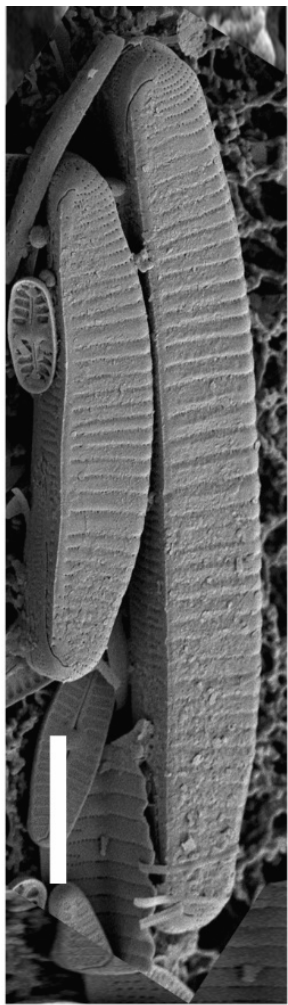

(b)

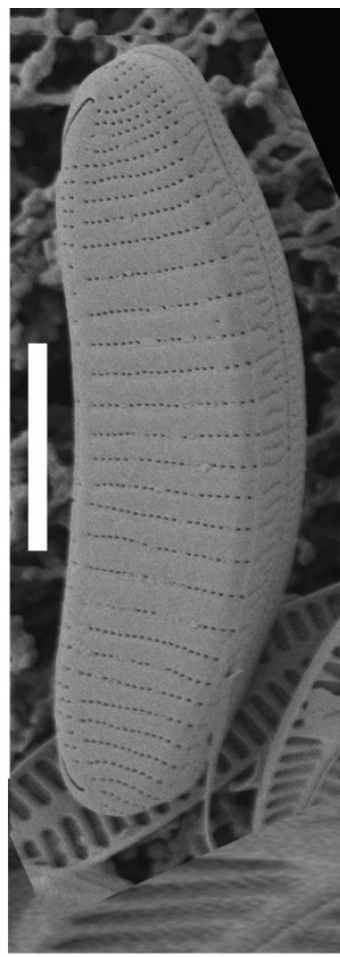

(c) (d)

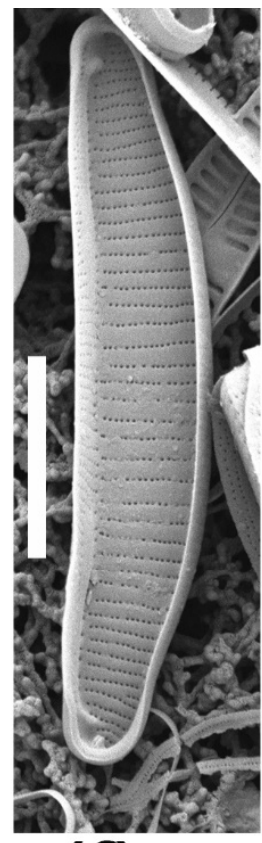

(f)

(e)

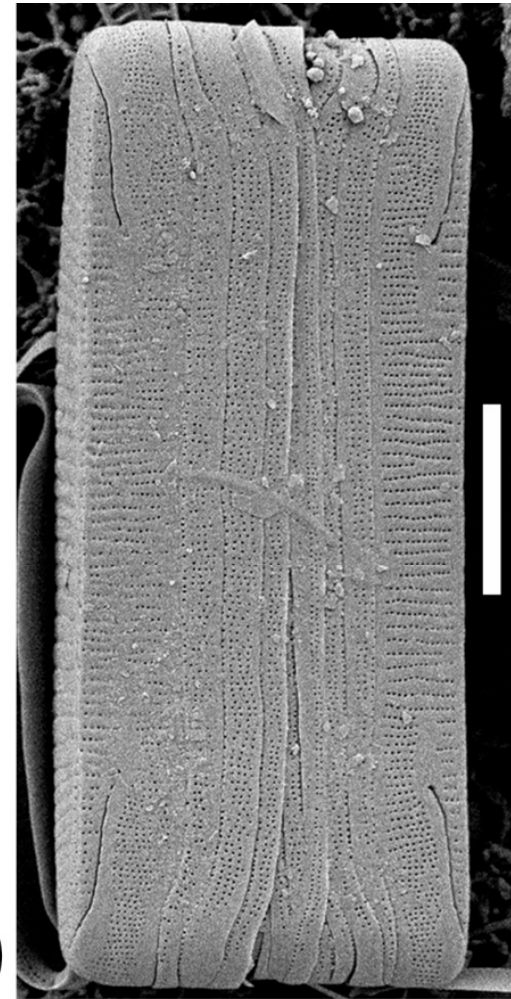

(g)

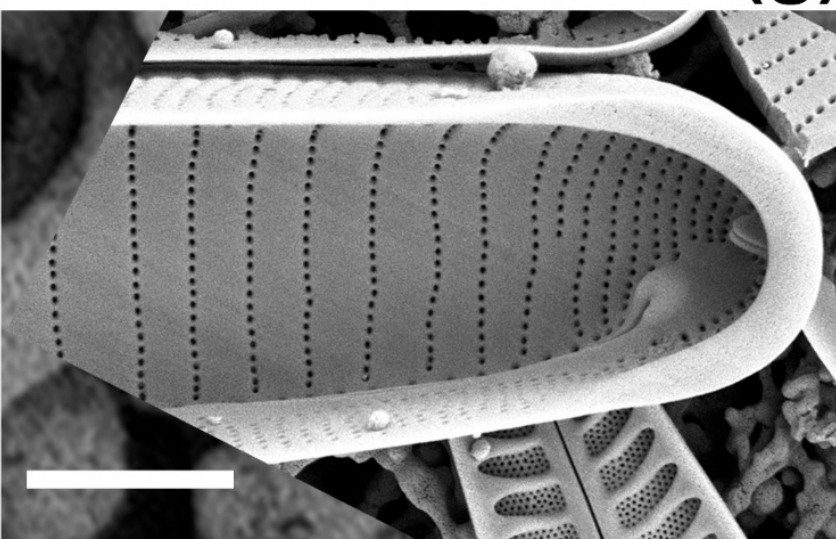

Figure 2. (a-g). SEM images of Eunotia crassiminor Lange-Bert. et Cantonati sp. nov. (a-e): External views. (f,g): internal views. Scale bars $10 \mu \mathrm{m}(\mathbf{a}-\mathbf{c}, \mathbf{e}, \mathbf{f}), 4 \mu \mathrm{m}(\mathbf{g}), 3 \mu \mathrm{m}(\mathbf{a}-\mathbf{c}, \mathbf{e}, \mathbf{f})$.

Synonymy. Eunotia minor sensu Lange-Bert. et al. [16], Figure 159: 1-7.

To exclude from synonymy: Eunotia minor sensu Lange-Bert. et al. [16], Figure 159: $12-27$.

Differential diagnosis versus Eunotia minor (Kütz.) Grunow [referred to Himanthidium minus Kütz., 1844, Material Kützing N. 30 from Jever, leg. Koch (=B.M. 17863), see [16], Figure 158: 14-17. Frustule morphology as in E. minor but specimens on average larger, appearing more strongly silicified. (Figure $1 \mathrm{~h}$, i provides a comparison for the girdle view, and Figure $1 \mathrm{~m}, \mathrm{n}$ for the valve view). Valve outline and shape variability during the cell cycle barely different. Length 28-63 (vs. 14-44) $\mu \mathrm{m}$, breadth 6.0-8.0 (vs. 3.5-5.0) $\mu \mathrm{m}$. Raphe course with terminal fissures not different. Transapical striae proximally 6-10 (vs. 10-17) in $10 \mu \mathrm{m}$, becoming rather abruptly much more densely spaced at the ends, 16-20 (vs. 
becoming gradually denser up to $18-20)$ in $10 \mu \mathrm{m}$. Areolae precisely to count only with electron microscopical techniques.

As is typical for the genus, two elongate chromoplasts lying on the ventral side of the cell and extending onto the valve faces (Figure $1 \mathrm{j}, \mathrm{k}$ ).

SEM (Figure 2)

External view: Areolae 33-36 (vs. 39-41) in $10 \mu \mathrm{m}$. Sternum (=ventral area) broader in comparison. Most remarkable distinguishing character a delicate ridge on both valve margins at the junction between face and ventral/dorsal mantles (e.g., Figure 2a,b,d). Ridges lacking in E. minor (e.g., Figure 160: 1-2 in Lange-Bertalot et al. [16]) but present even in small cell-cycle stages of E. crassiminor (Figure 19).

Only one valve pole with a rimoportula in both taxa (Figure 2d,g). A faint pseudoseptum sometimes developed at the poles (Figures 23 and 24).

Other characters seen with light microscopy (e.g., striae becoming abruptly much denser towards the poles, e.g., Figure $2 b$ ) could be confirmed.

Type material. HOLOTYPE. Diatom collection of the MUSE-Museo delle Scienze, Trento, Italy, TR, slide cLIM007 DIAT 1971 (Mt. Penna spring, bryophytes). Collected by M. Cantonati on the 25 th of July 2011. The holotype material is shown in Figure $1 \mathrm{a}-\mathrm{h}, \mathrm{j}-\mathrm{m}$ and Figure $2 \mathrm{a}-\mathrm{g}$.

ISOTYPES. Diatom Collection of the Academy of Natural Sciences of Drexel University, Philadelphia, PA, USA: ANSP GC14462 (slide), ANSP GCM15149 (cleaned material), ANSP GCM15150 (raw material); -Botanical Museum of the University of Berlin, Germany: B 40 0,041,535 (slide), B 40 0,041,536 (cleaned material), B 40 0,041,537 (raw material).

REGISTRATION.-http:/ / phycobank.org/102929

Type locality. Monte Penna spring (EBERs Project code: MtPe_ShFS-Hi, [1]). Shaded (Sh) Flowing Spring (FS) with the crustose red alga Hildenbrandia (Hi). Coordinates: Longitude: $9^{\circ} 30^{\prime} 29.493^{\prime \prime}$ E, Latitude $44^{\circ} 29^{\prime} 6.029^{\prime \prime}$ N. 1324 m a.s.l. Lithology: ophiolite (basalts) hard rock aquifer.

Etymology. Resembles E. minor but is larger and with a more robust structure.

Distribution. As yet critically observed with SEM and distinguished from E. minor in several springs with low conductivity in the south-eastern Alps and in the Northern Apennine but probably occurring elsewhere under appropriate conditions, waiting for critical differentiation from other morphodemes of E. minor sensu lato. At the type locality, the new species was more abundant in the epibryon than in the epilithon (relative abundance: 4.9 vs. $2.3 \%$, respectively).

Ecology, co-occurring diatom species, and associated photoautotrophs. Environmental conditions at the type locality: Discharge $\left(\mathrm{L} \mathrm{s}^{-1}\right): 3.5$, Temperature $\left({ }^{\circ} \mathrm{C}\right): 5.3$, conductivity $\left(\mu \mathrm{S} \mathrm{cm}{ }^{-1}\right)$ : 62, alkalinity ( $\left.\mu \mathrm{eq} \mathrm{L}^{-1}\right)$ : 311, $\mathrm{pH}: 6.6$, nitrate $\left(\mathrm{mg} \mathrm{L}^{-1}\right): 1.2, \mathrm{TP}\left(\mu \mathrm{g} \mathrm{L}^{-1}\right)$ : 7 (see [1] for more details). As concerns photoautotrophs, in this very shaded source the competitive balance between large groups (algae, lichens, bryophytes, and vascular plants) is clearly favorable to the mosses, which cover almost all the lithic substrata [dominance of Brachythecium rivulare W.P. Schimper, both submerged and, in large portions, emerged, and a certain relevance of Plagiomnium undulatum (Hedw.) T.J. Kop. and Rhizomnium punctatum (Hook.) T.J. Kop.]. Vascular plants are not abundant (as cover), and Adenostyles glabra (Miller) DC. and Saxifraga rotundifolia L. can be mentioned among them. In terms of cover, bryophytes are followed by lichens. These include two species which are rarely reported in Italy: Verrucaria madida Orange, an amphibious species in frequently flooded sites on siliceous rocks, often in association with other aquatic lichens and bryophytes, and Verrucaria aquatilis Mudd., common both in springs and along streams, in conditions of perennial/frequent submersion. Benthic macroalgae are rare and mainly represented by the red freshwater alga Hildenbrandia rivularis (Liebmann) J. Agardh, which is characteristic of shaded springs with well-buffered waters and medium-high conductivity.

The main co-occurring diatom species at the type locality (at least 5\% relative abundance in one of the slides): Achnanthidium minutissimum sp. gr., Amphora inariensis Krammer, Amphora indistincta Levkov, Brachysira exilis (Kütz.) Round and D.G.Mann Cocconeis pseu- 
dolineata (Geitler) Lange-Bert., Gomphonema elegantissimum E.Reichardt and Lange-Bert., Humidophila perpusilla (Grunow) Lowe, Kociolek, J.R.Johansen, Van de Vijver, Lange-Bert. and Kopalová, Planothidium angustilanceolatum sp. nov., P. frequentissimum (Lange-Bert.) Lange-Bert., P. lanceolatum, Psammothidium grischunum Bukht. and Round.

Ecology (Table 1, Figure 3a-1). With reference to temperature, E. crassiminor has a lower optimum weighted average than E. minor (Table 1); consistently, E. crassiminor also seems to prefer sites which are more shaded (Figure $3 b$ ). As concerns $\mathrm{pH}$ (Figure 3e), interestingly, E. crassiminor appears to prefer circumneutral values whilst $E$. minor occurs at slightly acidic ones. E. crassiminor has a higher weighted average for sulphates whilst E. minor has a higher optimum for manganese (Table 1). In particular, with reference to nitrogen, E. crassiminor appears to be associated with more strict oligotrophy than E. minor.

(a)

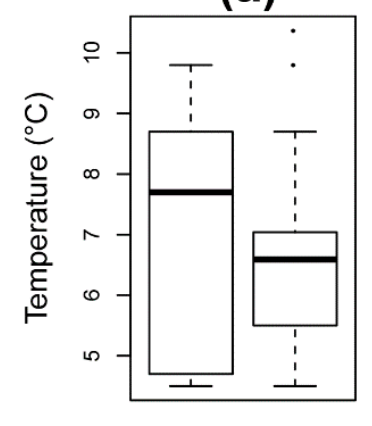

(b)

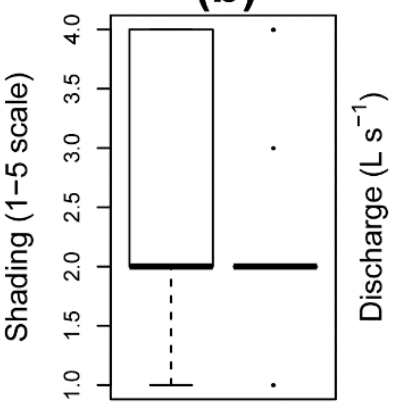

(c)

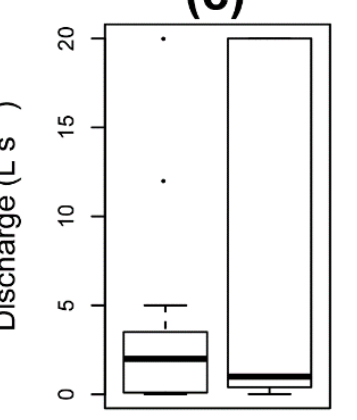

(d)

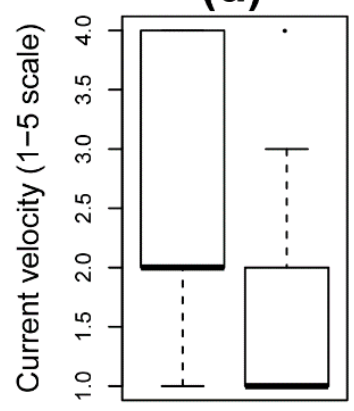

(e)

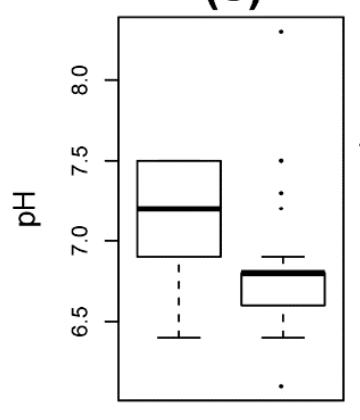

(f)

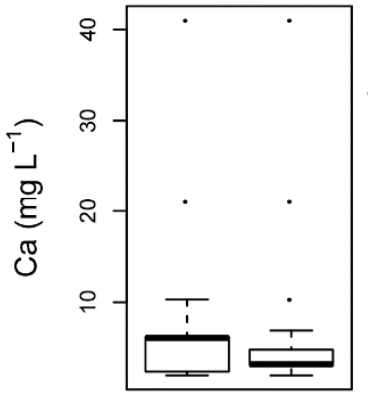

(g)

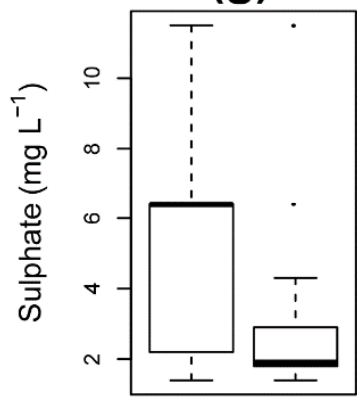

(h)

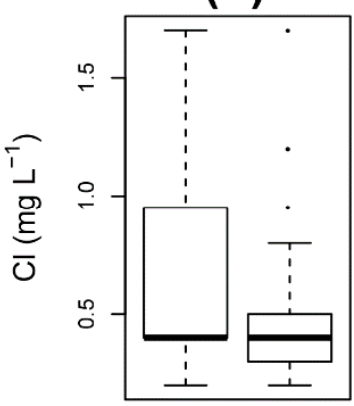

(i)

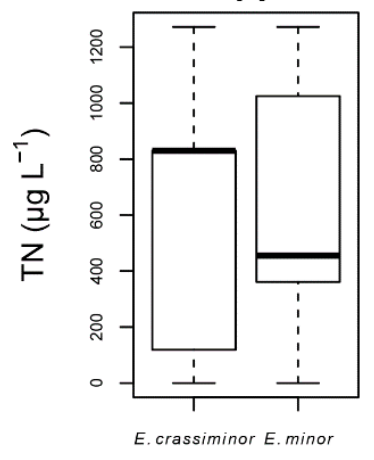

(j)

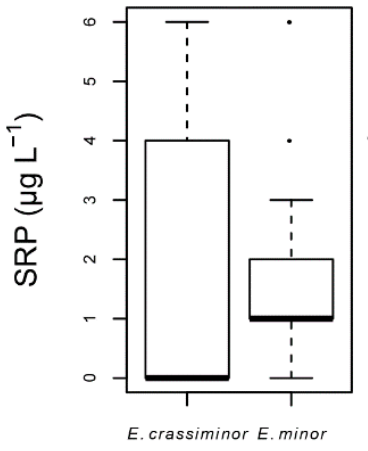

(k)

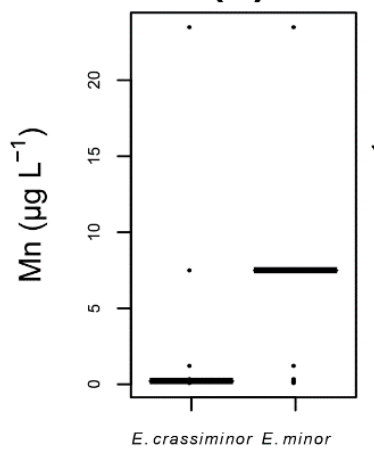

(I)

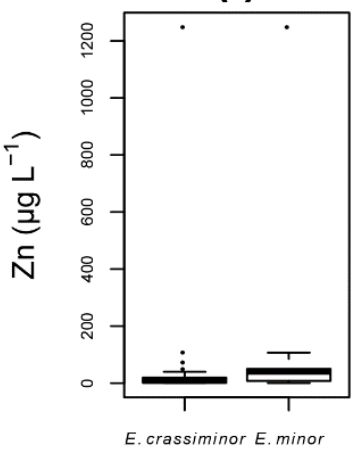

Figure 3. (a-1). Box and whisker plots showing the ecological preferences of Eunotia crassiminor as compared to E. minor. Only environmental factors/parameters for which statistically significant differences could be found are shown. 
Table 1. Ecological preferences of Eunotia crassiminor as compared to E. minor. Only environmental factors/parameters for which statistically significant differences could be found are shown.

\begin{tabular}{|c|c|c|c|c|c|c|c|c|}
\hline \multirow[b]{2}{*}{ Factor } & \multicolumn{3}{|c|}{ Eunotia crassiminor } & \multicolumn{3}{|c|}{ Eunotia minor } & \multicolumn{2}{|c|}{$t$-Tests } \\
\hline & Weighted Average & Min & Max & Weighted Average & Min & Max & $t$-Value & $p$-Value \\
\hline Temperature $\left({ }^{\circ} \mathrm{C}\right)$ & 5.6 & 4.5 & 9.8 & 7.8 & 4.5 & 8.7 & 7.58 & $5.99 \times 10^{-11}$ \\
\hline Shading (1-5 scale) & 3 & 1 & 4 & 2 & 2 & 2 & -9.08 & $1.20 \times 10^{-14}$ \\
\hline Discharge $\left(\mathrm{L} \mathrm{s}^{-1}\right)$ & 2.0 & 0.0 & 5.0 & 4.3 & 0.0 & 20.0 & 2.0 & $4.85 \times 10^{-2}$ \\
\hline Current velocity (1-5 scale) & 3 & 1 & 4 & 2 & 1 & 3 & -6.07 & $2.33 \times 10^{-8}$ \\
\hline $\mathrm{pH}$ & 6.8 & 6.4 & 7.5 & 7.0 & 6.4 & 6.9 & 2.8 & $6.11 \times 10^{-3}$ \\
\hline $\mathrm{Ca}^{2+}\left(\mathrm{mg} \mathrm{L}^{-1}\right)$ & 4.9 & 2.0 & 10.3 & 8.5 & 2.0 & 6.9 & 2.20 & $3.11 \times 10^{-2}$ \\
\hline Sulphates $\left(\mathrm{mg} \mathrm{L}^{-1}\right)$ & 5.1 & 1.4 & 11.5 & 2.2 & 1.4 & 4.3 & -7.39 & $1.45 \times 10^{-11}$ \\
\hline $\mathrm{Cl}^{-1}\left(\mathrm{mg} \mathrm{L}^{-1}\right)$ & 0.4 & 0.2 & 1.7 & 0.8 & 0.2 & 0.8 & 4.53 & $2.28 \times 10^{-5}$ \\
\hline $\mathrm{TN}\left(\mu \mathrm{g} \mathrm{L}^{-1}\right)$ & 340 & 0 & 1272 & 649 & 0 & 1272 & 4.29 & $7.69 \times 10^{-5}$ \\
\hline $\operatorname{SRP}\left(\mu \mathrm{g} \mathrm{L}^{-1}\right)$ & 2 & 0 & 6 & 2 & 0 & 3 & -2.25 & $2.69 \times 10^{-2}$ \\
\hline $\operatorname{Mn}\left(\mu \mathrm{g} \mathrm{L}^{-1}\right)$ & 0.6 & 0.2 & 0.2 & 9.8 & 7.5 & 7.5 & 4.95 & $2.59 \times 10^{-5}$ \\
\hline $\mathrm{Zn}\left(\mu \mathrm{g} \mathrm{L}^{-1}\right)$ & 101 & 0 & 40 & 37 & 0 & 107 & -2.12 & $3.56 \times 10^{-2}$ \\
\hline
\end{tabular}

Taxonomic comments. The obvious heterogeneity of various morphodemes and problems of identity concerning type and typification of Eunotia minor (Kütz.) Grunow have been discussed at length by Lange-Bertalot et al. ([16], pp. 157-160, Figure captions of plates 158-164). Whilst the true identity of Himanthidium minus Kütz. is not yet quite clear, E. crassiminor from the south-eastern Alps can be defined taxonomically and is well characterized from the morphological and ecological standpoints. It was possible to find associated in a single sample from a helocrenic spring in the Apennines (Elocrena Lago Scuro) E. minor and E. crassiminor, both never converging and easy to distinguish with the light microscope. E. crassiminor roughly resembles E. pomeranica Lange-Bert., Bak et Witkowski [16] from peat bogs in north-western Poland. However, the latter differs by almost evenly spaced striae in the proximal and distal parts of the valve, 11-15 and 16-18 in $10 \mu \mathrm{m}$, respectively. The amount of areolae and striae in the new described species is less than in similarly compared species. Marginal ridges in SEM view are missing.

Planothidium angustilanceolatum Lange-Bert. et Cantonati sp. nov. (Figures 4 and 5)

Differential diagnosis compared with an associated population of Planothidium lanceolatum (Bréb. ex Kütz.) Lange-Bert. Specimens with conspicuously narrower valves, concerning in particular medium-sized and smaller cell-cycle stages. Valves linear-elliptic with rounded ends (vs. broadly elliptic to elliptic-lanceolate with broadly rounded ends). Largest stages rhombic-lanceolate). Length 5-24 $\mu \mathrm{m}$, breadth $2.5-4 \mu \mathrm{m}$ (vs. 13-32 and 5-7.5 $\mu \mathrm{m}$, respectively). Length-to-breadth ratio $2.8-5.8$ (vs. 1.6-4.7). Areae, raphe, and striae are barely different in both taxa, stria density $12-16$ in $10 \mu \mathrm{m}$, considerably variable in both taxa.

As is typical for the genus, one chromoplast, in girdle view lying against the more convexly curved valve but extending under the other one; only moderate indentation between the two shorter lobes (Figure $4 \mathrm{~m}-\mathrm{O}$; Planothidium lanceolatum plastid shown for comparison in Figure $\left.4 a^{\prime}, b^{\prime}\right)$. 


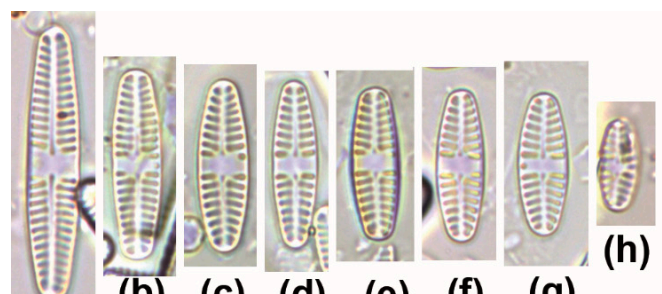

(a)

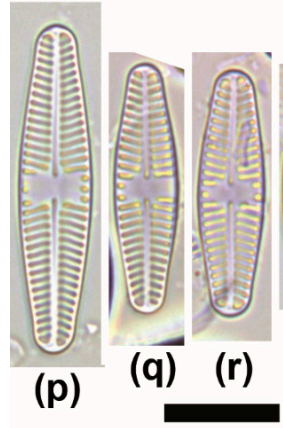

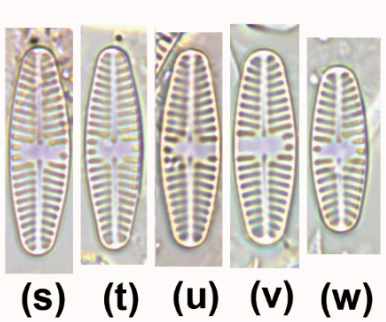

(s) (t) (u) (v) (w)

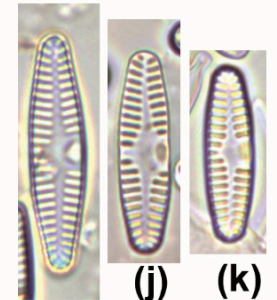

(i)

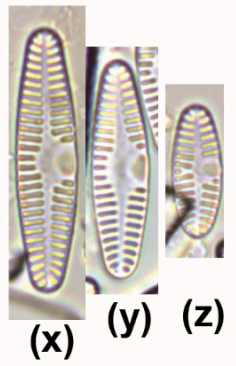

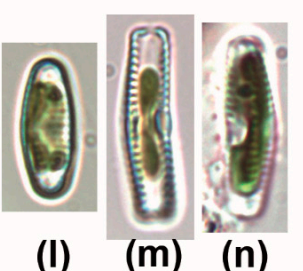

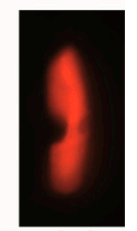

(0)

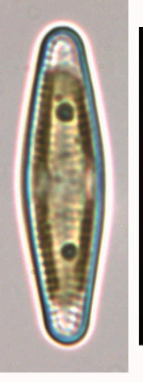

(a')

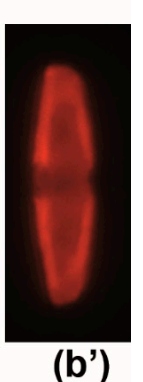

(b')

Figure 4. (a-h). LM morphology of Planothidium angustilanceolatum sp. nov. (a-o) as compared to a population of Planothidium lanceolatum co-occurring at the type locality $\left(\mathbf{p}-\mathbf{b}^{\prime}\right)$. All bright-field micrographs with the exception of $\left(\mathbf{o}, \mathbf{b}^{\prime}\right)$ which are based on chlorophyll autofluorescence. All valve views, with the exception of $(\mathbf{m}, \mathbf{n})$ that are girdle views. $(\mathbf{a}-\mathbf{h}, \mathbf{p}-\mathbf{w})$ : Raphe valves. (i-k, $\mathbf{x}-\mathbf{z})$ : Rapheless valves. (1-o, $\left.\mathbf{a}^{\prime}, \mathbf{b}^{\prime}\right)$ : Chromoplast morphology. Scale bar $10 \mu \mathrm{m}$.

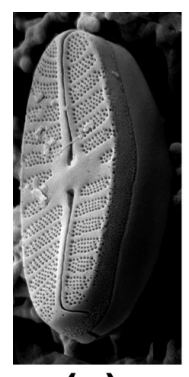

(a)

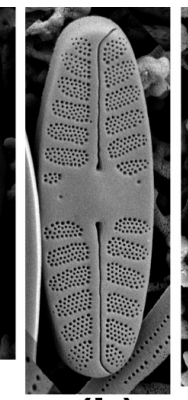

(b)

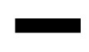

(c)

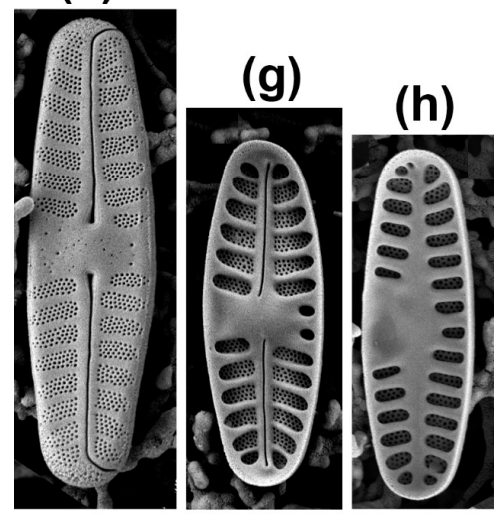

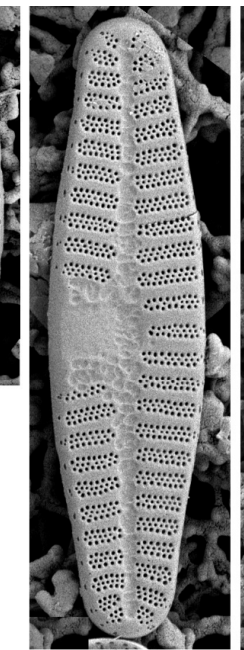

(e)

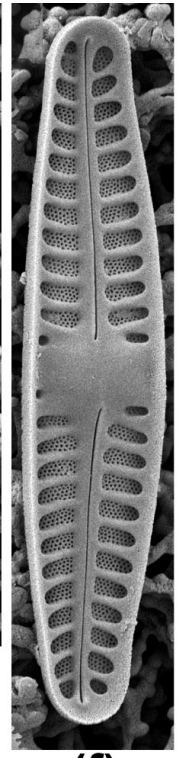

(f)

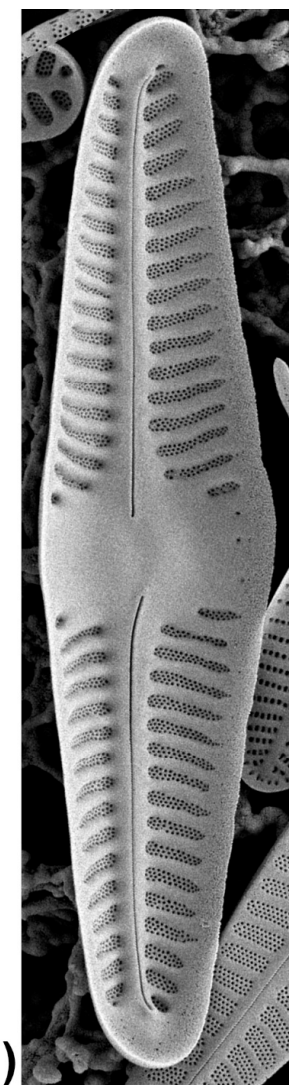

Figure 5. (a-i). SEM images of Planothidium angustilanceolatum Lange-Bert. et Cantonati sp. nov. $(\mathbf{a}-\mathbf{h})$, and of $P$. lanceolatum for comparison (i). (a-e): External views. (f-i): Internal views. (a-c,f,g,i): Raphe valves. (d,e,h): Rapheless valves. Scale bar $1 \mu \mathrm{m}$. 
SEM (Figure 5).

Externally the areae of raphid valves are smooth (Figure $5 b$ ), whereas the araphid valves are covered by shallow irregular grooves on both the axial and the central area (Figure $5 \mathrm{~d}, \mathrm{e}$ ), the latter more extended but not restricted unilaterally. The pluriseriate areolae ( $3-5$ series) extend more or less clearly over the valve face margins onto the mantle. More in rapheless (Figure 5d) and less in raphid (Figure 5c) valves. The characteristic unilateral depression, "sinus", of rapheless valves is very shallow comparatively (Figure $5 \mathrm{~d}$,e).

Type material. HOLOTYPE. Diatom collection of the MUSE-Museo delle Scienze, Trento, Italy, TR, slide cLIM007 DIAT 1971. The holotype material is shown in Figures 4a-o and $5 \mathrm{a}-\mathrm{h}$.

ISOTYPES. Diatom Collection of the Academy of Natural Sciences of Drexel University, Philadelphia, PA, USA: ANSP GC14463 (slide), ANSP GCM15151 (cleaned material), ANSP GCM15152 (raw material); Botanical Museum of the University of Berlin, Germany: B 40 0,041,538 (slide), B 40 0,041,539 (cleaned material), B 40 0,041,540 (raw material).

REGISTRATION. http:/ / phycobank.org/102930

Type locality. Monte Penna spring (EBERs Project code: MtPe_ShFS-Hi, [1]). Shaded (Sh) Flowing Spring (FS) with the crustose red alga Hildenbrandia (Hi) (see the description of Eunotia crassiminor for complete information).

Etymology. Resembles P. lanceolatum but is narrower.

Distribution. As yet critically observed exclusively at the type location in the Northern Apennines and in a spring with very similar hydrochemistry in the southeastern Alps (Belvedere spring epibryon: 3.7\% Planothidium angustilanceolatum sp. nov., 15.6\% Planothidium lanceolatum). At the type locality, the new species was clearly more abundant in the epibryon than in the epilithon (relative abundance: $13.6 \%$ vs. $5.4 \%$, respectively).

Ecology, co-occurring diatom species, and associated photoautotrophs. See the description of Eunotia crassiminor sp. nov. for complete information.

The search for this new species in ten comparable CRENODAT springs allowed us to find it in the low-conductivity high-mountain (2056 $\mathrm{m}$ a.s.l.) spring Belvedere (CRENODAT Project code: OC2056). Environmental conditions at Belvedere spring: Discharge ( $\left.\mathrm{L} \mathrm{s}^{-1}\right): 2$, Temperature $\left({ }^{\circ} \mathrm{C}\right): 4.5$, conductivity $\left(\mu \mathrm{S} \mathrm{cm}^{-1}\right): 60$, alkalinity ( $\left.\mu \mathrm{eq} \mathrm{L}^{-1}\right): 360, \mathrm{pH}: 6.9$, nitrate (mg L $\left.{ }^{-1}\right)$ : 0.48, TP $\left(\mu \mathrm{g} \mathrm{L}^{-1}\right): 5$.

Taxonomic comments. Obviously Planothidium lanceolatum sensu stricto is the closest related taxon. A population, probably identical with the P. lanceolatum type, is associated in the samples from the type locality. Geitler [15] described the entire cell cycle of Achnanthes lanceolata (syn. Planothidium lanceolatum): length of the auxospores (apical axis) 32-36, rarely up to $40 \mu \mathrm{m}$; copulating cells (gametes) $11-16$, rarely up to $20 \mu \mathrm{m}$; smallest cells length: $7 \mu \mathrm{m}$; breadth, transapical axis, of post-initial cells $8-10 \mu \mathrm{m}$, of copulating cells $5-7 \mu \mathrm{m}$, of smallest specimens $4.5-5 \mu \mathrm{m}$, resulting in a length-to-breadth ratio of 4.1, 2.5, and 1.6, respectively. The cultured clones originate from the calcium-carbonate-rich, oligotrophic Lake Lunz in the Austrian northern Alps. The valve outlines documented by line drawings are broadly elliptical in smallest stages and elliptic-lanceolate to rhombic-lanceolate. All with broadly rounded ends. Valve outlines conforming to P. angustilanceolatum do not occur. Stria density 13-14 in $10 \mu \mathrm{m}$. On the other hand, various photographically documented specimens from all continents conform to Geitler's description as far as P. lanceolatum sensu stricto is concerned, excluding many misidentified similar taxa. Examples are given by Rumrich et al. ([61], Figure 28: 11-16) from the Andes in Chile, $4000 \mathrm{~m}$ a.s.l., Sonneman et al. ([62], p. 15, Figure 10a-d) from Australia, Dorofeyuk and Kulikovskiy ([63], Figure 41: 1-8, 14-29, Figure 45: 1-4, 46: 1-6 from Mongolia, Metzelin et al. ([64], Figure 28: 1-8) from Mongolia, Blanco ([65], Figure 44: 1-22) from Spain, Wojtal ([66], Figure 138: 11-22) from Poland, Van de Vijner et al. ([67], Figure 23: 7-14, 24: 8-a) from the Ile Crozet Archipelago, Sub Antarctica.

Other, just roughly similar taxa with comparable size and outlines are: P. frequentissimum (Lange-Bert.) Lange-Bert. in Metzelin et al. ([64], Figure 28: 9-11), P. aff. fragilarioides sensu Lange-Bert. et Krammer ([68], Figure 88: 16-21), both distinguished mainly by the 
presence of a horseshoe-shaped "cavum", P. aueri (Krasske) Lange-Bert. distinguished by striae consisting of biseriate areolae and a "cavum".

Geitler ([15], p.41, Figure 64a-d) mentioned and displayed by line drawings smaller specimens that occurred together with P. lanceolatum, 8-10 $\mu \mathrm{m}$ long, $4 \mu \mathrm{m}$ broad, resembling but not identical with $P$. angustilanceolatum sp. nov. Later on, [69] validly established Achnanthes lanceolata var. minor (Schulz) Lange-Bert. as an infraspecific taxon, with a type originating from the Botanical Garden of Vienna, Austria, distinguished by conspicuously lower dimensions. Length was $6.5-21 \mu \mathrm{m}$, breadth 3.2-6 $\mu \mathrm{m}$; copulating cells (gametes) were 6.5-9.5 $\mu \mathrm{m}$ long, ca. $3.9 \mu \mathrm{m}$ broad, primary (initial) cells $18.5-21 \mu \mathrm{m}$ long and $5.5 \mu \mathrm{m}$ broad. Very likely this taxon is not a synonym of P. angustilanceolatum sp. nov. The valves of primary cells possessed rhombic outlines, i.e., inflated in the central part, whereas $22 \mu \mathrm{m}$ long stages of $P$. angustilanceolatum sp. nov. are distinguished by non-inflated linear to slightly linear-lanceolate outlines. Moreover, the distinctly contoured "horseshoe"shaped depressions of the rapheless valves of $A$. lanceolata var. minor point to a covered "cavum" rather than to a shallow open depression ("sinus"). Photographically documented specimens identified by Reichard ([70], Figure 7: 13-15) as Geitler's taxon display that character clearly. Thus, it appears to be more closely related to $P$. frequentissimum and $P$. frequentissimum var. minus (Shulz) Lange-Bert. rather than to P. lanceolatum sensu stricto.

Biometry of Planothidium angustilanceolatum sp. nov. at the type locality, compared with a co-occurring population of P. lanceolatum (Table 2, Figure 6a-e). By means of the biometry part of the study we could confirm that width (Table 2, Figure 6b) and length (Table 2, Figure 6a) differ in a statistically significant way between the Planothidium angustilanceolatum sp. nov. and P. lanceolatum population, being larger in the latter species. This is underlined also by the length-width relationships plotted in Figure 6e.

Delicatophycus crassiminutus Lange-Bert. et Cantonati sp. nov. (Figures 7 and 8)

Light microscopy. Valves rather weakly dorsiventral, lanceolate, ends distinctly protracted rostrate-subcapitate (Figure 7a-i). Length $18-27 \mu \mathrm{m}$, breadth $3.5-5 \mu \mathrm{m}$ proximally, becoming ca. $2 \mu \mathrm{m}$ below the expanded ends, maximum length-to-breadth ratio 6.2. Axial area narrow, curved, extended gradually to the valve centre, slightly displaced to the ventral side. No set off central area developed, since dorsal striae commonly not, occasionally very little shortened gradually, never abruptly and barely wider spaced than the subproximal striae (Figure $7 \mathrm{~d}-\mathrm{g}$ ). Occasionally the area system even appears slightly constricted in the centre. Raphe strongly reverse-lateral towards proximal ends. Terminal fissures comma-shaped and dorsally bent (see SEM). Dorsal striae radiate throughout, 15-16 in $10 \mu \mathrm{m}$. Ventral striae are distinctly more narrowly spaced, 18-21 in $10 \mu \mathrm{m}$, the median ones at most very little radiate. Areolation of the striae is indistinctly resolvable in LM.

As is typical for the genus, one highly-lobed chromoplast lying with its centre against the ventral side of the girdle but extending under each valve with longitudinal indentations (H-shaped); pyrenoid on the dorsal side of the cell (Figure 7k,l).

SEM. External and internal views see Figure 8a,b. Basic pattern of the fine structures is principally the same as in other taxa of the genus, particularly D. minutus M.J.Wynne. However, the wavy appearance of fusing areolae externally is less expressed in our materials probably due to corrosion effects, see likewise Figure $8 \mathrm{c}$ for D. minutus. Areola density $35-44$ in $10 \mu \mathrm{m}$. Proximal raphe ends deflected to the ventral side, distal ends strongly bent onto the dorsal mantle, sickle-shaped. Striae in the subcapitate ends become subparallel on the dorsal side, even convergent on the ventral side. 
Table 2. Morphological characteristics of Planothidium angustilanceolatum sp. nov. at the type locality, compared with a co-occurring population of P. lanceolatum.

\begin{tabular}{|c|c|c|c|c|c|c|c|c|c|c|c|c|c|c|c|c|c|c|}
\hline & \multicolumn{6}{|c|}{ P. angustilanceolatum } & \multicolumn{6}{|c|}{ P. lanceolatum } & \multicolumn{6}{|c|}{$t$-Tests } \\
\hline & \multicolumn{3}{|c|}{ R-Valves } & \multicolumn{3}{|c|}{ RL-Valves } & \multicolumn{3}{|c|}{ R-Valves } & \multicolumn{3}{|c|}{ RL-Valves } & \multicolumn{3}{|c|}{ R-Valves } & \multicolumn{3}{|c|}{ RL-Valves } \\
\hline & Mean & Min & Max & Mean & Min & $\operatorname{Max}$ & Mean & Min & Max & Mean & Min & $\operatorname{Max}$ & $t$-Value & $d f$ & $p$-Value & $t$-Value & $d f$ & $p$-Value \\
\hline Length $(\mu \mathrm{m})$ & 14.9 & 7.9 & 24.5 & 14.0 & 7.9 & 24.1 & 18.8 & 12.8 & 29.1 & 18.9 & 11.7 & 27.4 & 5.12 & 99 & $1.51 \times 10^{-6}$ & 6.86 & 101 & $5.44 \times 10^{-10}$ \\
\hline Length/Width & 3.6 & 2.6 & 5.7 & 3.6 & 2.4 & 5.8 & 3.6 & 2.8 & 4.9 & 3.7 & 2.6 & 5.4 & -0.09 & 75 & $9.28 \times 10^{-1}$ & 0.78 & 117 & $4.38 \times 10^{-1}$ \\
\hline Striae in $10 \mu \mathrm{m}$ & 13 & 12 & 14 & 13 & 12 & 14 & 13 & 12 & 16 & 13 & 12 & 14 & 1 & 88 & $1.84 \times 10^{-1}$ & 0.21 & 114 & $8.37 \times 10^{-1}$ \\
\hline
\end{tabular}



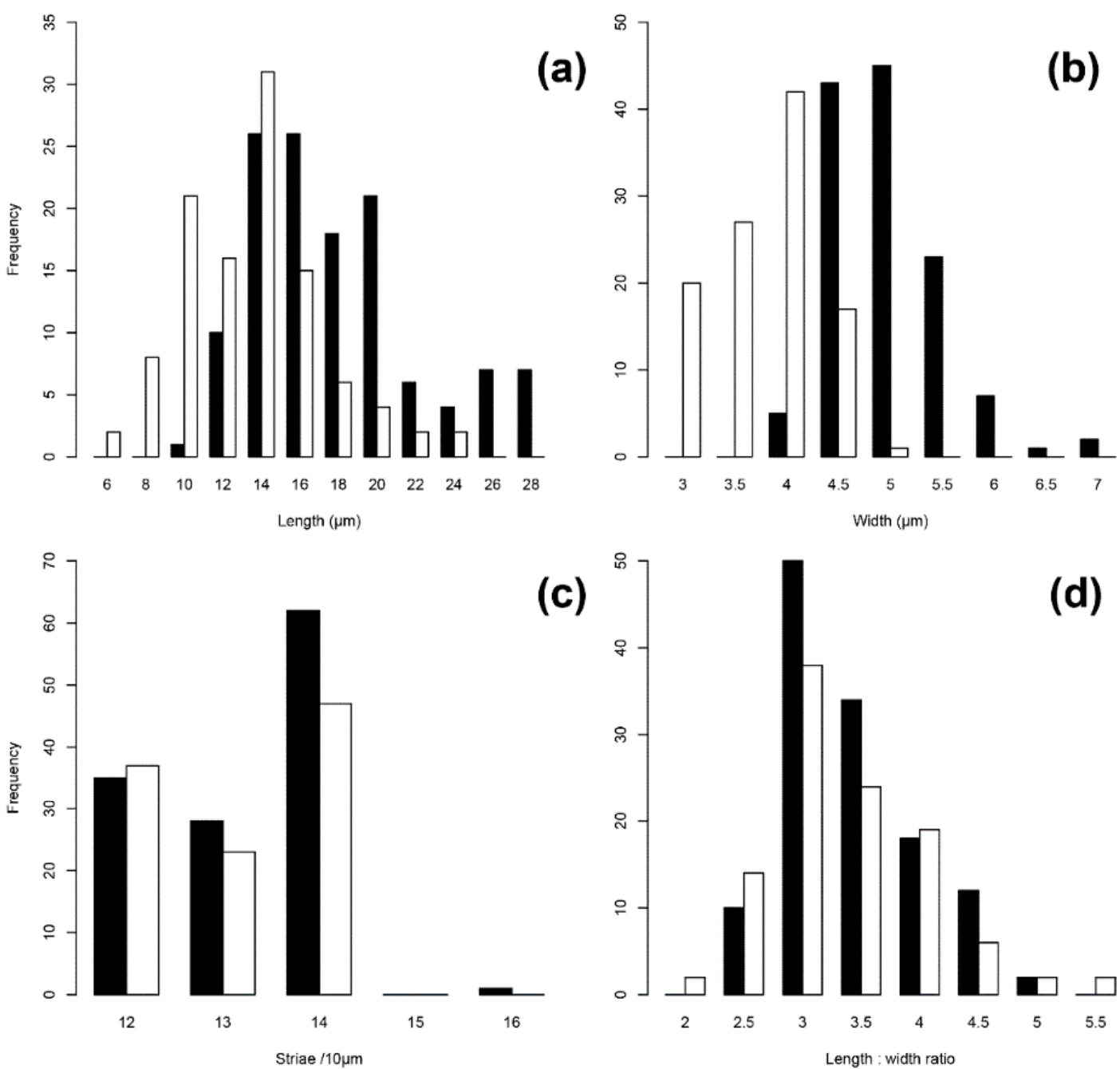

(c)
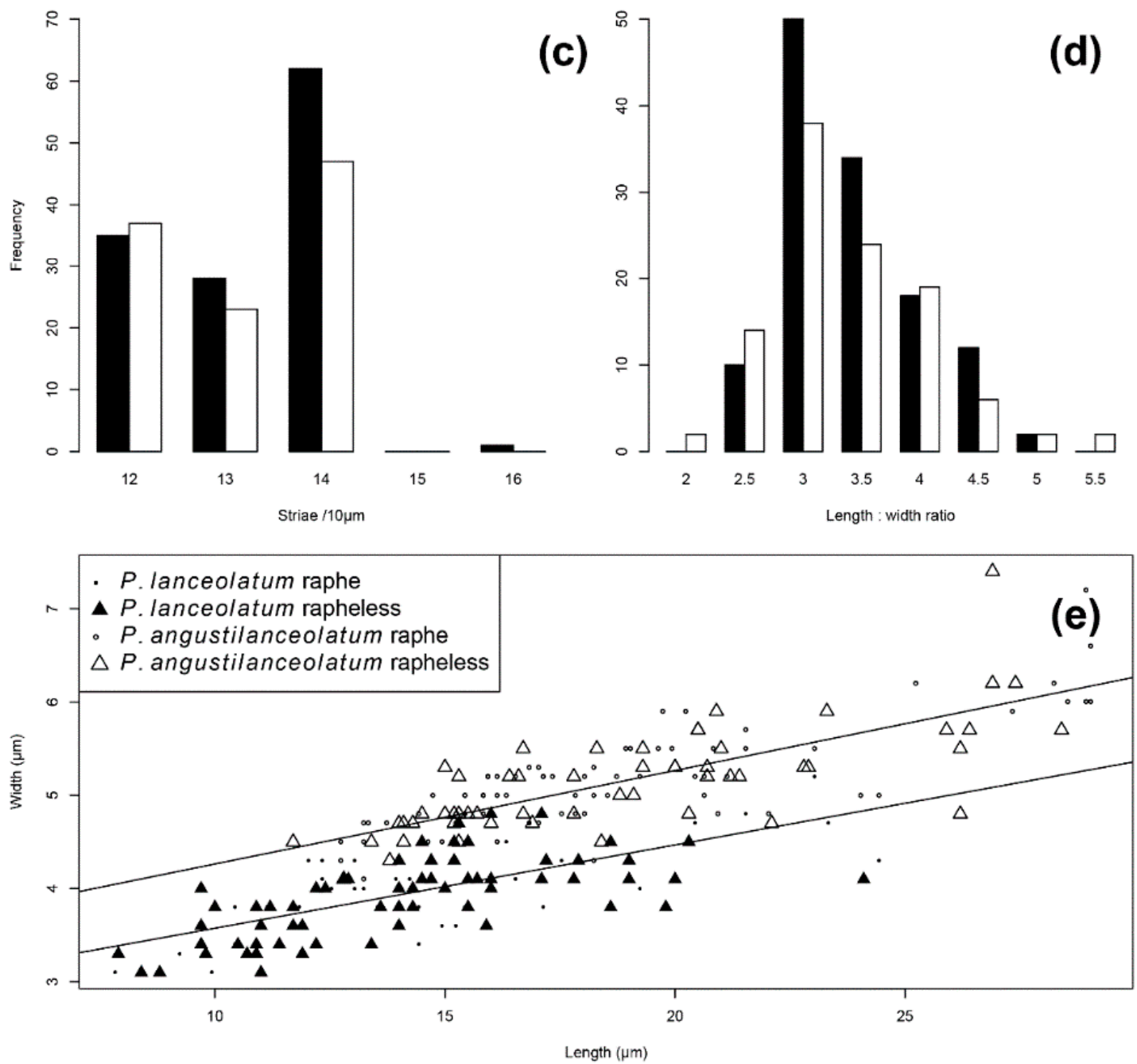

Figure 6. (a-e) Morphological characteristics of Planothidium angustilanceolatum sp. nov. at the type locality, compared with a co-occurring population of P. lanceolatum. 


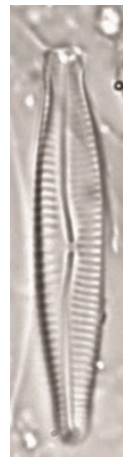

(a)

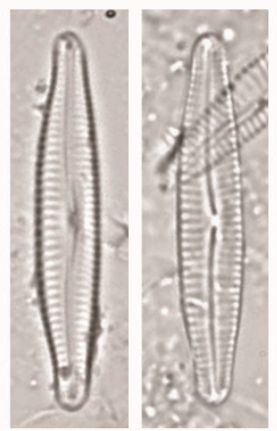

(b)

(c)

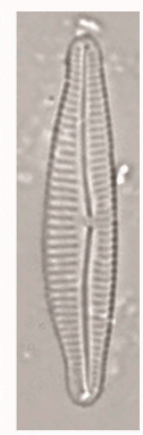

(d)

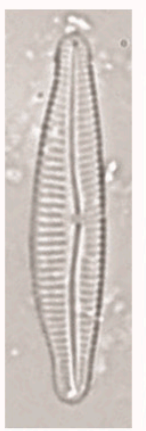

(e)

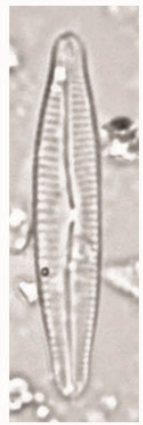

(f)

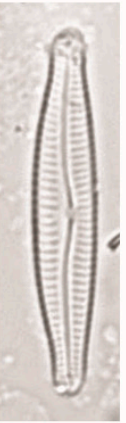

(g)

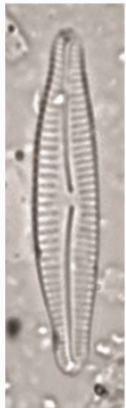

(h)

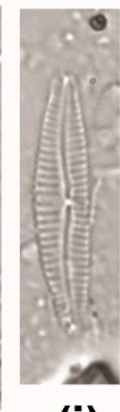

(i)

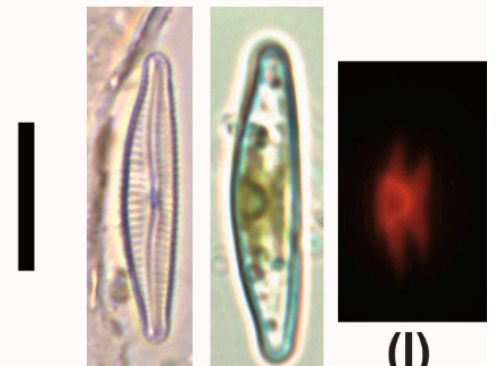

(j) (k)

Figure 7. (a-1). LM morphology of Delicatophycus crassiminutus Lange-Bert. et Cantonati sp. nov. (a-i,k,1), and of D. minutus (j) for comparison. All bright-field micrographs with the exception of (1) which is based on chlorophyll autofluorescence. (k,1): Chromoplast morphology. Scale bar $10 \mu \mathrm{m}$.

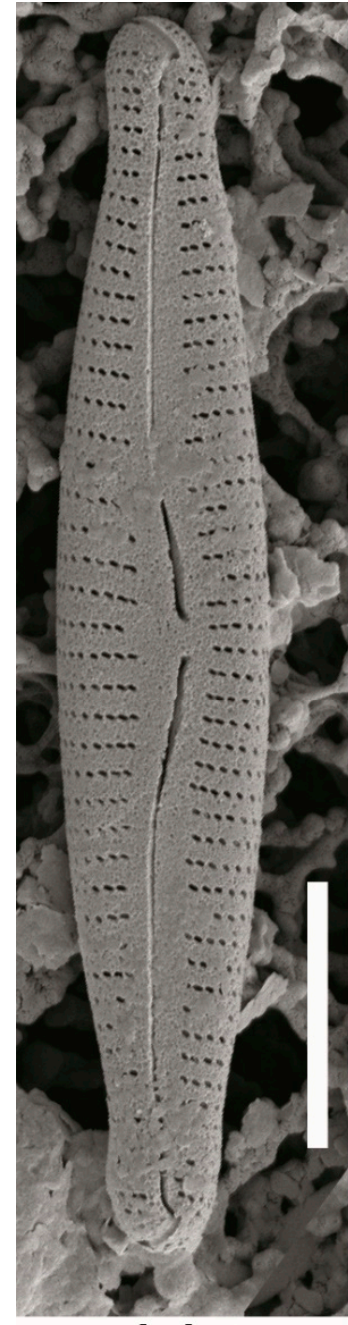

(a)

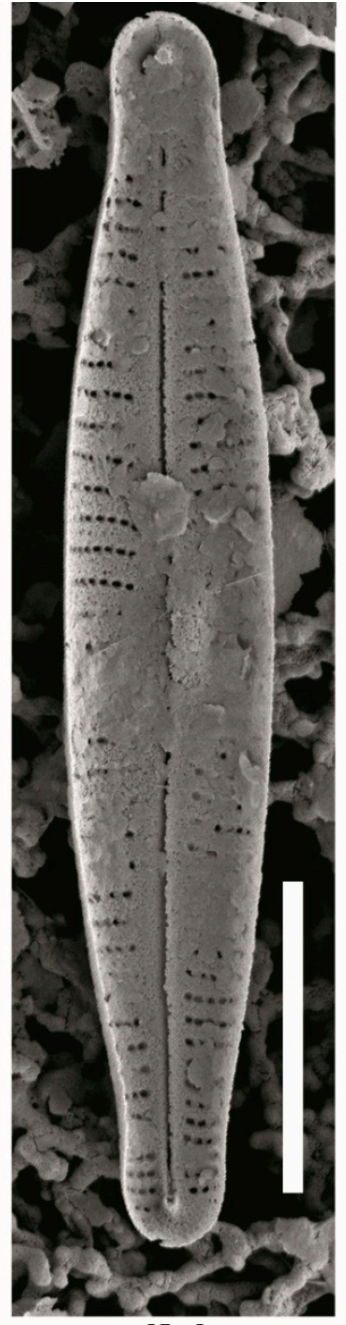

(b)

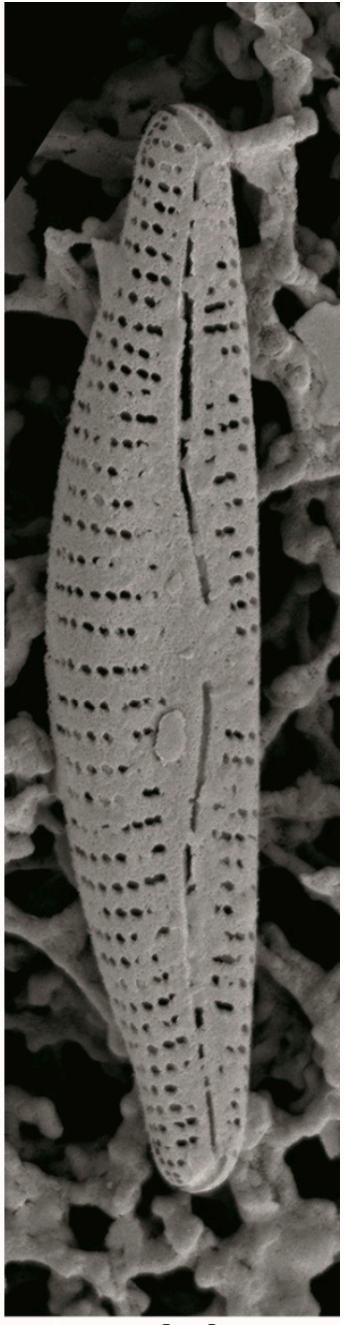

(c)

Figure 8. (a-c). SEM images of Delicatophycus crassiminutus Lange-Bert. \& Cantonati sp. nov. (a,b), and of D. minutus for comparison (c). (a,c): External views. (b): Internal view. Scale bars $5 \mu \mathrm{m}$. 


\section{Type material.}

HOLOTYPE. Diatom collection of the MUSE-Museo delle Scienze, Trento, Italy, TR, slide cLIM007 DIAT 1962 (Carameto spring, epilithon). Collected by M. Cantonati on the 28th of July 2011. The holotype material is shown in Figure 7a-i,k,l and Figure 8a,b.

ISOTYPES. Diatom Collection of the Academy of Natural Sciences of Drexel University, Philadelphia, PA, USA: ANSP GC14464 (slide), ANSP GCM15153 (cleaned material), ANSP GCM15154 (raw material); -Botanical Museum of the University of Berlin, Germany: B 40 0,041,541 (slide), B 40 0,041,542 (cleaned material), B 40 0,041,543 (raw material).

REGISTRATION.-http:/ / phycobank.org/102931

Type locality. Carameto spring (EBERs Project code: Cara_LPS-sn, [1]). Small (s), nearnatural (n) limestone-precipitating spring (LPS). Coordinates: Longitude: $9^{\circ} 45^{\prime} 35.165^{\prime \prime} \mathrm{E}$, Latitude $44^{\circ} 39^{\prime} 50.840^{\prime \prime}$ N. 758 m a.s.l. Lithology: limestones, flyschs; calcarenites.

Distribution. At the type locality, the new species was found only in the epilithon (relative abundance: 2.2\%). Observations on CRENODAT materials confirmed that the species is restricted to LPS springs.

Ecology, co-occurring diatom species, and associated photoautotrophs. Environmental conditions at the type locality: Discharge $\left(\mathrm{L} \mathrm{s}^{-1}\right)$ : 0.07 , Temperature $\left({ }^{\circ} \mathrm{C}\right): 12.8$, conductivity $\left(\mu \mathrm{cm}^{-1}\right): 462, \mathrm{HCO}_{3}{ }^{-}\left(\mathrm{mg} \mathrm{L}^{-1}\right): 145$, $\mathrm{pH}: 7.7$, nitrate $\left(\mathrm{mg} \mathrm{L}^{-1}\right): 0.12$, TP $\left(\mu \mathrm{g} \mathrm{L}^{-1}\right.$ ): 6 (see [1] for more details). The vegetation occurring in the Carameto spring belongs to the Adiantion alliance with dominance of the characteristic bryophyte species Eucladium verticillatum Bruch and W.P. Schimper, Hymenostylium recurvirostrum (Hedw.) Dixon, and Pellia endiviifolia (Dicks.) Dumort. Other taxa occurring at the type locality, but all with low cover, were the bryophytes Bryum pseudotriquetrum (Hedw.) Gaertn., Meyer and Scherb. and Palustriella commutata Ochyra, and the vascular plants Carex flacca Schreb. and Molinia caerulea (L.) Moench. Species diversity was low (13 taxa), as expected in this kind of community [71].

Main co-occurring diatom species at the type locality (at least $5 \%$ relative abundance in one of the slides): Achnanthidium minutissimum sp. gr., Achnanthidium trinode Ralfs, Delicatophycus minutus, Denticula tenuis Kütz., Encyonopsis lange-bertalotii Krammer, Gomphonema tenoccultum E.Reichardt.

Taxonomic comments. Among the moderately few taxa of the genus, only D. minutus is actually similar (see [50], summarizing table of the taxa with illustrations (pp. 112-113). It differs mainly by more distinctly dorsiventral symmetry, missing set off ends, and presence of a central area dorsally. In SEM, external view ([50], Figure 137: 16), striae are distinctly radiate throughout; convergent striae on the dorsal side of the ends are lacking due to the simply rounded, not subcapitate ends. Moreover, D. minutus has a higher density of the central dorsal striae (16-21 vs. $15-16$ in $10 \mu \mathrm{m})$.

\section{Discussion}

Springs are a unique but severely threatened wetland type. Therefore, the in-depth knowledge of the taxonomy and ecology of characteristic diatom species is important because diatoms are excellent indicators of the quality and integrity of these peculiar ecosystems in the face of direct and indirect human impacts.

The three new species described differ morphologically from the most similar existing species by: less dense striae and areolae, and absence of a ridge at the valve face-mantle transition (SEM feature) (Eunotia crassiminor Lange-Bert. et Cantonati sp. nov.; closest established species: Eunotia minor); narrower and shorter cells (Planothidium angustilanceolatum Lange-Bert. et Cantonati sp. nov.; closest established species: Planothidium lanceolatum); barely-dorsiventral symmetry, set off ends, and lower density of the central dorsal striae (Delicatophycus crassiminutus Lange-Bert. et Cantonati sp. nov.; closest established species: Delicatophycus minutus).

Two of the three species we described are separated from the most similar established species by dimensions. By applying Krammer's [13] ratio of maximal and minimal width as a reliable means to test the quality of taxa, we find that we have contributed to improve 
knowledge on two taxa (Eunotia minor s.l. and Planothidium lanceolatum s.1.), which are likely to be only partially resolved complexes of species because they have a max-min width ratio of 2 and 2.2, respectively (data of minimum and maximum width taken from [72].

We also could contribute to ameliorate knowledge on the ecological profiles of the three newly described species. In the case of Eunotia crassiminor sp. nov. data were sufficient to allow testing for statistical significance. Eunotia crassiminor sp. nov. as compared to Eunotia minor, appears to occur in colder inland waters with circumneutral $\mathrm{pH}$, and strict oligotrophy also with respect to nitrogen. In the face of global warming, diffuse airborne nitrate pollution, and acidification risk, this realized ecological niche singles out Eunotia crassiminor sp. nov. as a species which is clearly more threatened than E. minor. This information is very useful as well for the generation and updating of diatom Red Lists that can provide excellent metrics for the conservation value of inland waters [5]. As far as the other two newly described species are concerned, data gained on the distribution were too few to allow for statistical treatment. However, they occur in spring types which are so peculiar that some generalization, though with caution, can be made. Planothidium angustilanceolatum sp. nov. was found only in two springs, one in the Northern Apennines and one in the south-eastern Alps, that however have almost identical morphological, physical, and chemical characteristics. It can thus be stated that the typical habitat of this species is oligotrophic mountain flowing springs with low conductivity (approximately $\left.60 \mu \mathrm{S} \mathrm{cm}{ }^{-1}\right)$. Delicatophycus crassiminutus sp. nov. was observed only in LPS, and is therefore likely to be restricted to hard water springs and comparable habitats where $\mathrm{CO}_{2}$ degassing leads to carbonate precipitation.

The correct knowledge of the taxonomy and ecology of the species occurring in mountain aquatic habitats is of great importance to use diatoms as reliable indicators of environmental and climate change. Mountain ecosystems are sensitive and reliable indicators of climate change (e.g., [73]). There are many good reasons for protecting these freshwater habitats [74]: they are relatively scarce, provide clean water for many uses, harbour a large number of Red List taxa [compare $[7,74]$, and they are sensitive to disturbance from human activities $[7,12]$.

Author Contributions: Conceptualization, M.C. and H.L.-B.; methodology, M.C., N.A. and L.v.W.; validation, M.C. and H.L.-B.; formal analysis, L.v.W. and M.C.; investigation, M.C. and N.A.; resources, M.C.; data curation, M.C. and N.A.; writing-original draft preparation, M.C. and O.B.; writing-review and editing, M.C., O.B., H.L.-B. and L.v.W.; visualization, N.A. and M.C.; supervision, M.C. and H.L.-B.; project administration, M.C.; funding acquisition, M.C. All authors have read and agreed to the published version of the manuscript.

Funding: The study (EBERs Project) generating the data on which the descriptions of the three new species are based was funded by the Geological Survey of the Emilia-Romagna Region (Italy).

Institutional Review Board Statement: Not applicable.

Informed Consent Statement: Not applicable.

Data Availability Statement: The data presented in this study are available on request from the corresponding author.

Acknowledgments: Authors other than H.L.B. are most glad to use the occasion of the publication of this paper to celebrate the 85th birthday of Horst Lange-Bertalot acknowledging his outstanding contributions to the taxonomy and ecology of diatoms. We are grateful to the Geological Survey of the Emilia-Romagna Region (in particular Stefano Segadelli) for fostering the EBERs (Exploring the Biodiversity of Emilia-Romagna springs; 2011-2013) Project, in the frame of which samples on which the three species described as new in this paper were collected. We thank Daniel Spitale and Juri Nascimbene for useful information on the bryophytes + higher plants and the lichens of the type localities, respectively.

Conflicts of Interest: The authors declare no conflict of interest. 


\section{References}

1. Cantonati, M.; Segadelli, S.; Spitale, D.; Gabrieli, J.; Gerecke, R.; Angeli, N.; De Nardo, M.T.; Ogata, K.; Wehr, J.D. Geological and hydrochemical prerequisites of unexpectedly high biodiversity in spring ecosystems at the landscape level. Sci. Total Environ. 2020, 740, 140157. [CrossRef]

2. Cantonati, M.; Füreder, L.; Gerecke, R.; Jüttner, I.; Cox, E.J. Crenic habitats, hotspots for freshwater biodiversity conservation: Toward an understanding of their ecology. Freshw. Sci. 2012, 31, 463-480. [CrossRef]

3. Cantonati, M.; Stevens, L.; Segadelli, S.; Springer, A.; Goldscheider, N.; Celico, F.; Filippini, M.; Ogata, K.; Gargini, A. Ecohydrogeology: The interdisciplinary convergence needed to improve the study and stewardship of springs and other groundwaterdependent habitats, biota, and ecosystems. Ecol. Indic. 2020, 110, 1. [CrossRef]

4. Cantonati, M.; Fensham, R.J.; Stevens, L.E.; Gerecke, R.; Glazier, D.S.; Goldscheider, N.; Knight, R.L.; Richardson, J.S.; Springer, A.E.; Tockner, K. Urgent plea for global protection of springs. Conserv. Biol. 2021, 35, 378-382. [CrossRef]

5. Cantonati, M.; Hofmann, G.; Spitale, D.; Werum, M.; Lange-Bertalot, H. Diatom Red Lists: Important tools to assess and preserve biodiversity and habitats in the face of direct impacts and environmental change. Biodivers. Conserv. 2021. Accepted.

6. Cantonati, M.; Angeli, N.; Lange-Bertalot, H. Three new Fragilaria species (Bacillariophyta) from low-conductivity mountain freshwaters (Alps and Apennines). Phytotaxa 2019, 404, 261-274. [CrossRef]

7. Bahls, L. Diatom indicators of climate change in Glacier National Park. Intermt J. Sci. 2007, 13, 99-109.

8. Cantonati, M.; Segadelli, S.; Ogata, K.; Tran, H.; Sanders, D.; Gerecke, R.; Rott, E.; Filippini, M.; Gargini, A.; Celico, F. A global review on ambient Limestone-Precipitating Springs (LPS): Hydrogeological setting, ecology, and conservation. Sci. Total. Environ. 2016, 568, 624-637. [CrossRef]

9. Cantonati, M.; Angeli, N.; Bertuzzi, E.; Spitale, D.; Lange-Bertalot, H. Diatoms in springs of the Alps: Spring types, environmental determinants, and substratum. Freshw. Sci. 2012, 31, 499-524. [CrossRef]

10. Werum, M.; Lange-Bertalot, H. Diatoms in springs, from Central Europe and elsewhere under the influence of hydrogeology and anthropogenic impages. Iconogr. Diatomol. 2004, 13, 1-417.

11. Cantonati, M.; Lange-Bertalot, H. Diatom biodiversity of springs in the berchtesgaden national park (north-eastern alps, germany) with the ecological and morphological characterization of two species new to science. Diatom Res. 2010, 25, 251-280. [CrossRef]

12. Cantonati, M.; Lange-Bertalot, H. Diatom monitors of close-to-pristine, very-low alkalinity habitats: Three new Eunotia species from springs in Nature Parks of the south-eastern Alps. J. Limnol. 2011, 70, 209-221. [CrossRef]

13. Krammer, K. Cymbella Diatoms of Europe, Diatoms of the European Inland Waters and Comparable Habitats; Lange-Bertalot, H., Ed.; A.R.G. Gantner Verlag K.G.: Rugell, Liechtenstein, 2002; Volume 3, pp. 1-584.

14. Maltsev, Y.; Maltseva, S.; Kociolek, J.P.; Jahn, R.; Kulikovskiy, M. Biogeography of the cosmopolitan terrestrial diatom Hantzschia amphioxys sensu lato based on molecular and morphological data. Sci. Rep. 2021, 11, 1-19. [CrossRef]

15. Geitler, L. Der Formwechsel der pennaten Diatomeen (Kieselalgen) Arch. Protistenkunde. 1932, 78, 1-226.

16. Lange-Bertalot, H.; Bak, M.; Witkowski, A. Eunotia and some related genera. In Diatoms of Europe. Diatoms of the European in-Land Water and Comparable Habitats; Lange-Bertalot, H., Ed.; A.R.G. Gantner Verlag K.G.: Rugell, Liechtenstein, 2011; Volume 6, pp. $1-747$.

17. Blasi, C.; Del Vico, E. High mountain vegetation of the Apennines. Ber. d. Reinh.-Tüxen-Ges. 2012, 24, 179-194.

18. Cantonati, M.; Angeli, N.; Lange-Bertalot, H.; Levkov, Z. New Amphora and Halamphora (Bacillariophyta) species from springs in the northern Apennines (Emilia-Romagna, Italy). Plant Ecol. Evol. 2019, 152, 285-292. [CrossRef]

19. Ehrenberg, C.G. Über ein aus Fossilen Infusorien Bestehendes, 1832 zu Brod Verbacknes Bergmehl von den Grenzen Lapplands in Schweden. Bericht über die zur Bekanntmachung Geeigneten Verhandlungen der Königl; Preuß. Akademie der Wissenschaften zu Berlin Erster Jarhrgang: Berlin, Germany, 1837; pp. 43-45.

20. Novitski, L.; Kociolek, P. Preliminary Light and Scanning Electron Microscope Observations of Marine Fossil Eunotia Species with Comments on the Evolution of the Genus Eunotia. Diatom Res. 2005, 20, 137-143. [CrossRef]

21. Luo, F.; You, Q.; Yu, P.; Pang, W.; Wang, Q. Eunotia (Bacillariophyta) biodiversity from high altitude, freshwater habitats in the Mugecuo Scenic Area, Sichuan Province, China. Phytotaxa 2019, 394, 133-147. [CrossRef]

22. Round, F.E.; Crawford, R.M.; Mann, D.G. The Diatoms: Biology and Morphology of the Genera; Cambridge University Press: Cambridge, CA, USA, 1990; pp. 1-747.

23. Kociolek, J.P.; Spaulding, S. Eunotioid and asymmetrical naviculoid diatoms. In Freshwater Algae of North America. Ecology and classification; Wehr, J.D., Sheath, R.G.F., Eds.; Academic Press Elsevier Science: London, UK, 2003; pp. 655-668.

24. Furey, P.C.; Lowe, R.L.; Johansen, R.J. Eunotia Ehrenberg (Bacillariophyta) of the Great Smoky Mountains National Park, USA. Biblioth. Diatomol. 2011, 56, 1-133.

25. Cox, E. Coscinodiscophyceae, Mediophyceae, Fragilariophyceae, Bacillariophyceae (Diatoms). In Syllabus of Plant Families. Adolf Engler's Syllabus der Pflanzenfamilien. 2/1 Photoautotrophic Eukaryotic Algae; Frey, W., Ed.; Borntraeger Science Publishers: Stuttgart, Germany, 2015; pp. 64-103.

26. Metzeltin, D.; Lange-Bertalot, H. Tropical diatoms of South America I: About 700 predominantly rarely known or new taxa representative of the neotropical flora. In Iconographia Diatomologica. Annotated Diatom Micrographs; Lange-Bertalot, H., Ed.; Diversity-Taxonomy-Geobotany, Koeltz Scientific Books: Königstein, Germany, 1998; Volume 5, pp. 1-695.

27. Liu, Y.; Wang, Q.; Fu, C. Taxonomy and distribution of diatoms in the genus Eunotia from the Da'erbin Lake and Surrounding Bogs in the Great Xing'an Mountains, China. Nova Hedwig 2011, 92, 205-232. [CrossRef] 
28. Ruwer, D.T.; Blanco, S.; Rodrigues, L. Eunotia Ehrenberg (Eunotiaceae, Bacillariophyta) in a subtropical floodplain: A new species and taxonomic contributions. Phytotaxa 2021, 505, 157-175. [CrossRef]

29. Round, F.E.; Bukhtiyarova, L. Four new genera based on Achnanthes (Achnanthidium) together with a re-definition of Achnanthidium. Diatom Res. 1996, 11, 345-361. [CrossRef]

30. Guiry, M.D.; Guiry, G.M. AlgaeBase. World-Wide Electronic Publication, National University of Ireland, Galway. 2021. Available online: https: / / www.algaebase.org (accessed on 1 October 2021).

31. Kociolek, J.P.; Blanco, S.; Coste, M.; Ector, L.; Liu, Y.; Karthick, B.; Kulikovskiy, M.; Lundholm, N.; Ludwig, T.V.; Potapova, M.; et al. DiatomBase. Available online: http:/ / www.diatombase.org (accessed on 27 October 2021).

32. Jahn, R.; Abarca, N.; Gemeinholzer, B.; Mora, D.; Skibbe, O.; Kulikovskiy, M.; Gusev, E.; Kusber, W.-H.; Zimmermann, J. Planothidium lanceolatum and Planothidium frequentissimum reinvestigated with molecular methods and morphology: Four new species and the taxonomic importance of the sinus and cavum. Diatom Res. 2017, 32, 75-107. [CrossRef]

33. Stancheva, R. Planothidium sheathii, a new monoraphid diatom species from rivers in California, USA. Phytotaxa 2019, 393, 131-140. [CrossRef]

34. Wetzel, C.E.; Van de Vijver, B.; Blanco, S.; Ector, L. On some common and new cavum-bearing Planothidium (Bacillariophyta) species from freshwater. Fottea 2019, 19, 50-89. [CrossRef]

35. Potapova, M.G. New species and combinations in monoraphid diatoms (family Achnanthidiaceae) from North America. Diatom Res. 2012, 27, 29-42. [CrossRef]

36. Wetzel, C.E.; Van De Vijver, B.; Hoffmann, L.; Ector, L. Planothidium incuriatum sp. nov. a widely distributed diatom species (Bacillariophyta) and type analysis of Planothidium biporomum. Phytotaxa 2013, 138, 43-57. [CrossRef]

37. Compère, P.; Riaux-Gobin, C. Diatomées de quelques biotopes marins, saumâtres et dulçaquicoles de Guinée (Afrique occidentale) [Diatoms from some marine, brackish and freshwater biotopes of Guinea (West Africa)]. Syst. Geogr. Plants 2009, 79, 33-66.

38. N'Guessan, K.R.; Wetzel, C.E.; Ector, L.; Coste, M.; Cocquyt, C.; Van de Vijver, B.; Yao, S.S.; Ouattara, A.; Kouamelan, E.P.; Tison-Rosebery, J. Planothidium comperei sp. nov. (Bacillariophyta), a new diatom species from Ivory Coast. Plant Ecol. Evol. 2014, 147, 455-462. [CrossRef]

39. Blanco, S.; Álvarez-Blanco, I.; Cejudo-Figueiras, C.; Recio Espejo, J.M.; Borja Barrera, C.; Bécares, E.; Díaz del Olmo, F.; Cámara Artigas, R. The diatom flora in temporary ponds of Doñana National Park (southwest Spain): Five new taxa. Nord. J. Bot. 2013, 31, 489-499. [CrossRef]

40. Lai, G.G.; Ector, L.; Padedda, B.M.; Wetzel, C.E. Planothidium marganaiensis sp. nov. (Bacillariophyta), a new cavum-bearing species from a karst spring in south-western Sardinia (Italy). Phytotaxa 2021, 489, 140-154. [CrossRef]

41. Kulikovskiy, M.S.; Lange-Bertalot, H.; Kuznetsova, I.V. Lake Baikal: Hotspot of endemic diatoms, 2. Iconogr. Diatomol. 2015, 26, $1-656$.

42. Van de Vijver, B.; Wetzel, C.; Kopalová, K.; Zidarova, R.; Ector, L. Analysis of the type material of Achnanthidium lanceolatum Brébisson ex Kützing (Bacillariophyta) with the description of two new Planothidium species from the Antarctic Region. Fottea 2013, 13, 105-117. [CrossRef]

43. Wetzel, C.E.; Ector, L. Planothidium lagerheimii comb. nov. (Bacillariophyta, Achnanthales) a forgotten diatom from South America. Phytotaxa 2014, 188, 261. [CrossRef]

44. Riaux-Gobin, C.; Witkowski, A.; Igersheim, A.; Lobban, C.S.; Al-Handal, A.Y.; Compère, P. Planothidium juandenovense sp. nov. (Bacillariophyta) from Juan de Nova (Scattered Islands, Mozambique Channel) and other tropical environments: A new addition to the Planothidium delicatulum complex. Fottea 2018, 18, 106-119. [CrossRef]

45. Cooper, J.T.; Steinitz-Kannan, M.; Kallmeyer, D.E. Bacillariophyta: The Diatoms. In Algae: Source of Treatment; Ripley, M.G., Ed.; American Water Works Association: Denver, CO, USA, 2010; pp. 207-249.

46. Stancheva, R.; Kristan, N.V.; Iii, W.B.K.; Sheath, R.G. Diatom genus Planothidium (Bacillariophyta) from streams and rivers in California, USA: Diversity, distribution and autecology. Phytotaxa 2020, 470, 1-30. [CrossRef]

47. Bak, M.; Halabowski, D.; Kryk, A.; Lewin, I.; Sowa, A. Mining salinisation of rivers: Its impact on diatom (Bacillariophyta) assemblages. Fottea 2020, 20, 1-16. [CrossRef]

48. Halabowski, D.; Bak, M.; Lewin, U. Distribution and ecology of two interesting diatom species Navicula flandriae Van de Vijver et Mertens and Planothidium nanum Bak, Kryk et Halabowski in rivers of Southern Poland and their spring areas. Oceanol. Hydrobiol. Stud. 2021, 50, 137-149. [CrossRef]

49. Wynne, M.J. Delicatophycus gen. nov.: A validation of "Delicata Krammer" inval. (Gomphonemataceae, Bacillariophyta). Not. Algarum 2019, 97, 1-3.

50. Krammer, K. Cymbopleura, Delicata, Navicymbula, Gomphocymbellopsis, Afrocymbella. In Diatoms of Europe, Diatoms of the Euro-Pean Inland Waters and Comparable Habitats; Lange-Bertalot, H., Ed.; A.R.G. Gantner Verlag, K.G.: Rugell, Liechtenstein, 2003; Volume 4, pp. 1-529.

51. Turland, N.J.; Wiersema, J.H.; Barrie, F.R.; Greuter, W.; Hawksworth, D.L.; Herendeen, P.S.; Knapp, S.; Kusber, W.-H.; Li, D.-Z.; Marhold, K. (Eds.) International Code of Nomenclature for Algae, Fungi, and Plants (Shenzhen Code) Adopted by the Nineteenth International Botanical Congress, Shenzhen, China, 23-29 July 2017; Koeltz Botanical Books: Glashütten, Germany, 2018; Volume 159, pp. 1-253. 
52. Cohu, R.L.; Lange-Bertalot, H.; Van de Viver, B.; Tudesque, L. Analysis and critical evaluation of structural features in four Cymbellaceae taxa from New Caledonia. Fottea 2020, 20, 75-85. [CrossRef]

53. Shi, Z.X. Flora algarum Sinicarum Aquae Dulcis, Vol. XVI, Bacillariophyta Cymbellaceae; Science Press: Beijing, China, 2013 ; pp. 1-217.

54. Liu, B.; Blanco, S.; Qing-Yan, L. Ultrastructure of Delicata sinensis Krammer et Metzeltin and D. williamsii sp. nov. (Bacillariophyta) from China. Fottea 2018, 18, 30-36. [CrossRef]

55. Metzeltin, D.; Lange-Bertalot, H. Tropical Diatoms of South America II. Special remarks on biogeography disjunction. Iconogr. Diatomol. 2007, 18, 1-877.

56. Bahls, L.L. Diatoms from Western North America 1. Some New and Notable Biraphid Species; Edited and Published by the Author: Helena, MT, USA, Montana Diatom Collection; 2017; pp. 1-52.

57. Liu, W.; Li, Y.-L.; Wu, H.; Kociolek, J.P. Delicatophycus liuweii sp. nov., a new cymbelloid diatom (Bacillariophyceae) from an upper tributary of the Liujiang River, Guangxi, China. Phytotaxa 2021, 505, 63-70. [CrossRef]

58. EN 13946. Water Quality. Guidance Standard for the Routine Sampling and Pretreatment of Benthic Diatoms from Rivers. 2003. Available online: http:/ /http:/ / www.safrass.com/partners_area/BSI\%20Benthic\%20diatoms.pdf (accessed on 1 October 2021).

59. Cox, E.J. Identification of Freshwater Diatoms from Live Material; Chapman and Hall: London, UK, 1996; p. 158.

60. Team, R.R. A language and Environment for Statistical Computing, Vienna, R Foundation for Statistical Computing. 2009. Available online: http:/ / www.R-project.org (accessed on 27 October 2021).

61. Rumrich, U.; Lange-Bertalot, H.; Rumrich, M. Diatomeen der Anden von Venezuela bis Patagonien/Feuerland und zwei weitere Beiträge. Diatoms of the Andes from Venezuela to Patagonia/Tierra del Fuego and two additional contributions. Iconogr. Diatomol. 2009, 9, 1-673.

62. Sonneman, J.A.; Sincock, A.; Fluin, J.; Reid, M.A.; Newall, P.; Tibby, J.; Gell, P. All Illustrated Guide to Common Stream Di-atom Species from Temperate Australia; Cooperative Research Centre for Freshwater Ecology: Thurgoona, Australia, 2000; pp. 1-168.

63. Dorofeyuk, N.I.; Kulikovskiy, M.S. Diatoms of Mongolia; Inst. Ecol. Evol. RAN: Moscow, Russia, $2012 ;$ pp. 1-367.

64. Metzeltin, D.; Lange-Bertalot, H.; Soninkhishig, N. Diatoms in Mongolia. Icon. Diatom. 2009, 20, 1-686.

65. Blanco, S.; Cejudo-Figueiras, C.; Álvarez-Blanco, I.; Bécares, E.; Hoffmann, L.; Ector, L. Atlas de las Diatomeas de la cuenca del Duero. Diatom atlas of the Duero Basin; Universidad de León: León, Spain, 2010; pp. 1-382.

66. Wojtal, A.Z.; Łukasz, S. The influence of substrates and physicochemical factors on the composition of diatom assemblages in karst springs and their applicability in water-quality assessment. Hydrobiol 2012, 695, 97-108. [CrossRef]

67. Van de Vijver, B.; Frenot, Y.; Beyens, L. Freshwater diatoms from Ile de la Possession (Crozet Archipelago, Subantarctica). Biblioth. Diatomol. 2002, 46, 1-412.

68. Lange-Bertalot, H.; Krammer, K. Achnanthes Eine Monographie der Gattung. Biblioth. Diatomol. 1989, $18,1-393$.

69. Geitler, L. Beiträge zur Entwicklungsgeschichte und Taxonomie einiger Achnanthes-Arten, Subgenus Microneis (Bacillariophyceae). Plant Syst. Evol. 1980, 134, 1-10. [CrossRef]

70. Reichardt, E. Die Diatomeen der Altmühl (Beitragë zur Diatomeenflora der Altmühl 2). Biblioth. Diatomol. 1984, 6, 1-169.

71. Zechmeister, H.; Mucina, L. Vegetation of European springs: High-rank syntaxa of the Montio-Cardaminetea. J. Veg. Sci. 1994, 5, 385-402. [CrossRef]

72. Cantonati, M.; Kelly, M.G.; Lange-Bertalot, H. Freshwater Benthic Diatoms of Central Europe: Over 800 Common Species Used in Ecological Assessment; Koeltz Botanical Books: Schmitten-Oberreifenberg, Germany, 2017; pp. 1-942.

73. Rogora, M.; Frate, L.; Carranza, M.L.; Freppaz, M.; Stanisci, A.; Bertani, I.; Bottarin, R.; Brambilla, A.; Canullo, R.; Carbognani, M.; et al. Assessment of climate change effects on mountain ecosystems through a cross-site analysis in the Alps and Apennines. Sci. Total. Environ. 2018, 624, 1429-1442. [CrossRef]

74. Bahls, L.; Pierce, J.; Apfelbeck, R.; Olsen, L. Encyonema droseraphilum sp. nov. (Bacillariophyta) and other rare diatoms from undisturbed floating-mat fens in the northern Rocky Mountains, USA. Phytotaxa 2013, 127, 32. [CrossRef] 